University of Louisville

ThinkIR: The University of Louisville's Institutional Repository

Electronic Theses and Dissertations

$1-1929$

\title{
Formal retraction or literary repentance in the Elizabethan Age.
}

Irene B. Rhoads

University of Louisville

Follow this and additional works at: https://ir.library.louisville.edu/etd

Part of the English Language and Literature Commons

\section{Recommended Citation}

Rhoads, Irene B., "Formal retraction or literary repentance in the Elizabethan Age." (1929). Electronic Theses and Dissertations. Paper 1200.

https://doi.org/10.18297/etd/1200

This Master's Thesis is brought to you for free and open access by ThinkIR: The University of Louisville's Institutional Repository. It has been accepted for inclusion in Electronic Theses and Dissertations by an authorized administrator of ThinkIR: The University of Louisville's Institutional Repository. This title appears here courtesy of the author, who has retained all other copyrights. For more information, please contact thinkir@louisville.edu. 


\title{
UNIVERSITY OF LOUISVILIE
}

\author{
FORMAL RETRACTATION OF LITERARY REPENTA NCE \\ in the \\ ELIZABETHAN AGE
}

\begin{abstract}
A Dissertation
Submitted to the Faculty

of the Graduate School of

The College of Arts and Sciences

In Partial Fulfillment of the Requirements

For the Degree of
\end{abstract}

MASTER OF ARTS

DEPARTMENT OF ENGLISH

by

IRENE B. RHOADS

1929 


\section{CONTENTS}

The Problem of Retractation

George Gascoigne

Robert Greene

Thomas Nash

Edmund Spenser

John Donne

Seventeenth Century Poets

Sumnary

Bibliography

16616 
THE PROBLEM OF RETRACTATION 
Before entering upon a discussion of those writers of the Elizabethan Age whose works present specific instances of Personal Retractation, let us turn our attention to the problem in general and try to find out why writers of this age and of earlier times felt it necessary to repent of their literary efforts.

Some critics may say that retractation was merely a literary convention; and why bother about its beginnings, sources, et cetera? Others may have the opinion that it was a personal trait, only a means of satisfying some peculiar whim or fancy of the author. Some may go even so far as to say it was one of the many tricks or devices which an author used in the attempt to get his works before the reading public.

Anyone, or all of these theories, may be true. We cannot say specifically that any one cause led to this old custom of confession in literature. To do so would mean that we are taking a narrow view of the subject. So in this study let us look not for one common cause, but for a combination of causes and interests which led writers of olden times to plainly confess the errors of their ways and to repent of their literary endeavors.

The Elizabethan writer was, to a great extent, bound by custom and tradition. He had not yet emerged from the repression and restraint of earlier times. He was seeking to depart from the beaten paths of literary 
tradition and really be himself. Now and then he burst forth in a flame of literary passion; but no sooner than this was do ne he turned from the "errors of his ways" and confessed his so-called sins. What caused the Elizabethan literary man to act in this way?

There are several factors, or forces, which I think entered into the making of the poet's mind a fertile field for the deep reflection which manifested itself in personal retractation or literary repentance:-

(1) Influence of the Middle Ages.

(2) The Position of the poet.

(3) Patronage.

(4)Authority and official Censorship.

(5) Puritanism.

(1) Influence of the Middle Ages.

The repentant attitude of the Elizabethan writer towards his literary productions is to some extent, an outgrowth of the mediaeval ideas of the purpose of poetry. The mediaeval poets were on the defensive. To justify art, the Middle Ages had to show its usefulness not only to morals, but to theology.

This medieeval conception of the purpose of literary art is reflected in the repentant attitude of many of the early writers. The custom or convention of literary repentance or retractation goes far back into literary history.

(1) Clark D. H.-Rhetoric and poetry in the Renaissance-page 128. 
The earliest and most important is St. Augustine's "Retractationes", which he wrote about the year 427. The second work of this kind is Bedes "Retractatio" written about the year 731. The third work to be noted is the "Retractationes" put by Gerald de Barri at the end of his "Descriptio Cambriae". (1)

Coming down through the ages we find Chaucer expressing deep regret for having written many of his works. Following the "Parson's Tale" the writer, speaking in his own person, asks the prayers of his readers that he may be forgiven, especially for his "translacions and endytings of worldly vanitees, the whiche I revoke in my retracciouns". It is hard to doubt that at least the title, perhaps the Idea also, is due directly or indirectly to either st: Augustine or Gerald. The resemblance is greater to Gerald's "Retractationes", appended to an earlier work, also expressing moral compunction. Either might have served to crystallize a narrowly pious impulse in the sick or aging Chaucer.

It is clear then that in early times the impulse, to express regret for and even to destroy works, which the over-sensitive conscience of elder years had thought blameworthy, revealed itself again and again.

With Chaucer there is to be considered the enormously strong pull of the whole spiritual teaching of the Middle Ages toward the ascetic attitude to worldly pleasure, which

(I) Tatlock, J. S. Publications Modern Language Assn. December 1913. Page 523.

(2) Ibid. Page 525. 
often has become stronger on a man as he has aged.

This same influence was carried on into the sixteenth century. The Elizabethan Age was an age of transition. As the term "transition" implies, conditions were in a flux, and ideas of the outworn past jostled ideas of the yet unborn future. Fngland was trying to emerge from the repression of past ages, but she was still influenced by old traditions and conceptions of the theory of literary productions and their purposes.

No doubt these beliefs and traditions of earlier ages influenced Elizabethan writers as regards their personal retractation or literary repentance.

(2) The Position of the poet.

The second factor to be considered in the problem of retractation in the Elizabethan Age is the position of the poet or literary man.

With all the professed love for poetry, the Elizabethan gentleman despised the professional poet. Snobbishness caused him to regard it as degrading to live by selling the product of one's labor. The common conception of poetry was low and trifling. Writing a poem hardly ranked even with honest manual labor.

It was to avoid the suspicion of living by his pen

(1) Sheavyn, Phoebe- The Literary Profession in the Elizabethan Age- Page 159. 
that the gentleman-poet refrained from publishing. Publication was descried as undignified and unworthy of a gentleman.

The low esteem in which professional writers were held cannot be ascribed entirely to the snobbish ignorance of the public. Some of the blame must attach to their own habits, often licentious and dissipated. They were but too commonly guilty of that vice of the age-- excess in drinking. Poets are regarded as "drunken parasites" (1)

Moreover, when considering the prevalent prejudice against writing for the press, we must not fail to notice the fact that authors probably shared in some of the odium caused by the practice of cheating publishers, who not infrequently cozened the reader by re-issuing old works with new titles, and binding up unsalable work with others for which there was plenty of sale. $\left(^{2}\right)$

Unfortunately, men who should have better understood the dignity of their art were sometimes led to defer to the judgment of critics and to make excuses and apologies for publishing. John Donne acknowledges it as a serious fault in himself "to have descended to print anything in verse". He wonders how he declined to it, and cannot pardon himself. (3)

The Elizabethan writer is not sure of himself. His

(1) Nash, Thos.- Summer's Last Will and Testament-Page 141.

(2) Nash, Thos. - Strange Newes- page 286.

(3) Gosse, E.- Life of Donne-Vol. I- Page 303. 
position is not secure. Criticism which is often very severe causes him to make apology for his work. "There were two chief standards of criticism in this age: one very commonly accepted by the general public-- based upon a purely

- moral criterion; the other, the classical, based upon literary conceptions, and adopted only by the cultivated few".

When we understand the position of the literary man in the days of Elizabeth, we are not surprised to find him confessing his so-called "sins" and making apology for having produced anything of a literary nature.

The custom of "retractio" is a weapon used by the Elizabethan writer to defend himself. In this age ofrestraint and repression of one's literary passions, was the author not justified in using retractation?

\section{(3) Patronage.}

The third factor to be considered is literary patronage in the Elizabethan Age.

The Elizabethan writer is, above all things, outspoken and impulsive, even childishly naive in self-exposure; and for our purposes, these characteristics are invaluable. As he remonstrates with his publisher, grumbles at his patron, and apologizes to his readers, he lets us into the secret of many things that would otherwise remain unknown or unintelligible.

(1) Sheavyn, Pheobe.- The Literary Profession in the Elizabethan Age. - Page 169. 
The literary man was, except in so far as he was maintained by patronage, in the economic position of an ordinary wage-earner.

It would appear that the immense output of literary

- work during the Elizabethan age was fostered very little by any enlightened encouragement; it was, in fact, produced in the face of most serious and disheartening hindrances. Only an exceptionally robust literary class could have withstood the withering effects of poetry, official interference, unfair competition, and scorn, with which they had to contend. (1)

In the Elizabethan Age the system of patronage was breaking down. Frequently the poet owned no natural patron; the patron himself had to be attracted by artificial means. He must be extolled for virtues raising him above the common run of benefactors. Hence extravagance in eulogy; hence servile humility in the writer; hence retractation.

(4) Authority or official Censorship.

Authority, or official censorship, is another important factor which led to the repentant atmosphere of the literary age. It is difficult for a modern writer to estimate the paralyzing influence of "authority" in Elizabethan days. In the sixteenth century, when the function of government in relation to literary production was mainly to pounce upon possible offenders, it was rare good fortune for

(1) Sheavyn, Phoebe. Op. cit., page 7 
the writer to succeed in eluding its grip.

The representatives of authority, so far as literature was concerned, were four: (1) The Court of High Commission, (2) The Privy Council and Court of Star Chamber,

.. (3) The Stationers' Company, and (4) The Corporation of the City of London. Authority, as exercised by these bodies, was throughout repressive. to regulations, fine and imprisonment, sometimes even banishment or death, were inflicted.

No wonder that writers constantly betrayed a nervous apprehension of the informers or "moralisers". They did their best to forestall these "moralisers" by assertions of innocence, and they guarded against their malice, wherever possible, by enjoying the patronage of some exalted personage.

We know from George Wither what his punishment was. He was confined in solitude, allowed to see no friends, forbidden to write. Sometimes for twenty-four hours together he was locked up "without as much as a drop of water to cool his tongue"!

It is certain that writers were intimidated, and that some were reduced to silence. Art was, as Shakespeare lamented, "made tongue-tied by Authority" (4) Nash declares

(1). Sheavyn, Phoebe- Op. cit., page 41.

(2) Sheavyn, Phoebe- page 44.

(3) Wither, George- Scholar's Purgatory-page 3.

(4) "Sonnets" - Number 66. 
that for a twelve month he published nothing for fear of censure. (1)

The result was the discredit into which malicious "moralisers" brought the whole profession of literature. It tended to diminish the credit of all writers and made the age afraid of its liberty.

Is it, then, unusual or astonishing to find authors

- burst forth into literary passion, only to retract their opinions as soon as they are expressed?

(5) Puritanism.

The last force to be considered is the influence of Puritanism upon the literature of the age.

One could speak at great length of the influence of Puritanism upon Elizabethan literature. It is not my purpose to treat this subject extensively, but only to mention it as one of the great underlying influences of the age. If we were studying together, not the literature of this period but its history, Puritanism would be the phase of English temper on which we might perhaps be forced to dwell most of all. And even our consideration of the national temper of England, as expressed in literature, cannot neglect it. "Elizabethan Puritanism was singularly inarticulate in literature; it left hardly any trace on the lasting surface of Elizabethan letters. Yet the national theme of

(1) Nash, Thomas- Summer's Last Will and Testament-page 87 
the period was immensely influenced by the temper of the Puritans"

The Puritans were opposed to all forms of literary endeavor. Their criticism was based largely upon the idea of its "falsity" and "frivolity", for such were the terms into which the sternly moral Elizabethan translated "imaginativeness" and "artistic beauty". Poets they regarded as "fantastic fools", if not worse. of Poetry", was the saying, "for it hath commonly one of these three properties, belibelling the wicked, abusing the honest, or pleasing the foolish".

Even Spenser had to bow to the hostile force of moral criticism. He acquiesced humbly in the judgment which condemned his beautiful and innocent poems on Love and Beauty, writing in atonement two other hymns on Heavenly Love and Heavenly Beauty.

Writers took pains to propitiate opinion, and advertised their wares on the title-pages as "profitable". Greene made the most wholesome attempts to conciliate public opinion. Several of his pamphlets, evidently intended as bids for the favor of the sober citizen, were devoted entirely to the discussion of moral aphorisms, enlivened by a few illustrated stories.

Practical statesmen like Burleigh joined forces with

(1) Wendell, Barrett- Temper of 17th Century in English

(2) Nash, Thomas- Piers Penniless-page 59.

(3) Breton, Nicholas-Works-Volume II- page 36. 
moral fanatics like stubbes in their suspicion of poetry;

but with the latter this hostility was based upon hatred of all pleasure, regarded as tending to withdraw the mind from contemplation of things spiritual, and thus endangering the salvation of the soul. The strict Puritan, with his ideal of a life spent in devotion to religious duties and contemplation, could not but abhor all pleasurable diversions.

All through the reign of James I the general interest in religious questions was deepening. In 1625, when Charles I succeeded his father, Puritanism had become so powerful a force in the country that it was clear it must, sooner or later, have a large influence upon the national literature. The poems of Herbert, Crashaw, Vaughan and Herrick show how effectively Anglicanism was working as a literary force.

No doubt Puritanism was one of the vital forces which caused the literary man of the Elizabethan Age to refrain from publishing the fruits of his pen, and which caused him to issue formal retractation in almost every form of literary endeavor.

As was said in the beginning of this discussion, no one cause, factor, force, or influence can be urged as the one impelling motive behind the age-old tradition or custom of literary repentance. The influences discussed here are, I think, the ones which point most clearly to the source

(1) Sheavyn, Phoebe- page 173.

(2) Cruse, A.-English Literature Through the Ages-page 196. 
of the problem.

These influences, added to the viewpoint of the proudly sensitive and serious artist, furnish sufficient reasons why the Elizabethan literary writer should so often turn aside from the theme of his work and pour out his heart to the reader in many forms of personal retractation or literary repentance. 
GEORGE GASCOIGNE 
George Gascoigne belongs to a period of literary transition. He stands, as it were, midway between the school of Surrey and the school of Spenser. He deserves

- to be regarded as one of the earliest of our strictly

- "vernacular" writers.

On the whole, Gascoigne is a thoroughly Elizabethan figure, alike in his character and his wórk, his license and his piety, his "Italianate" culture, and his unflagging interest in literary experiment. (I)

Gascoigne was highly esteemed in his own time. One of his contemporaries passed upon him a just and considerate verdict. Nashe says: (2) Maister Gascoigne is not to be abridged of his esteeme, who first beate the path to that perfection which our best poets have aspired to since his departure; whereto he did ascend by comparing the Italian with the English as Tully did 'Graeca cum Latinis'."

His character in its great versatility presents some of the features of the "Italianate Englishman"; and men of the next generation compared him with Robert Greene, whom he also resembles in the edifying tone with which, in his latter years, he speaks of the riots of his youth.

(1) Robertson, J. M.- Elizabethan Literature-page 65.

(2) McKerrow, R. B.- Works of Thomas Nashe-Vol.III-page 319.

(3) Courthope, W. J.- History of English Poetry-Vol II-P.I68. 
Before entering upon the study of his poetry it will be helpful for us to know something of the poet's Iife and the influences which were brought to bear upon his works. The following is a short sketch of the life of George Gascoigne:

George Gascoigne (1525?-1577) is an unusual instance of a poet who wrote, or at least published, nothing until past forty. He was the son of a Bedfordshire knight, and a descendant of the Chief Justice, who long, though it seems undeservedly, enjoyed the renown of having laid a Prince of Wales by the heels. Choosing the Prince rather than the ancestor for his model, Gascoigne, a gay young Templar, got himself disinherited for his dissolute courses, and spent his life under the pressure of debt, which he only partially relieved by marrying a widow in middle life. He was afterwards returned to Parliament for Midhurst, but, perhaps to frustrate the immunity from arrest which he would thus have obtained, was prevented from taking his seat by the machinations of his adversaries, who accused him, among the heinous offenses, of being "a common rhymer". To avoid persecution he went abroad, served with distinction in the Low Countries, was taken prisoner, and returned with "dulce bellum inexpertis" on his lips as the sum of his military experience. His services, it is likely, recommended him to the favour

(1) Garnett and Gosse- Illustrated History of English Literature-Vol.II, pagel 33. 
of Leicester, who employed him in writing and devising shows for the festivities at Kenilworth. Many of these are included in a volume entitled "The Princely Pleasures "at the Court of Kenilworth", published in 1576. Only the year before his death he produced his best known work, the satire entitled "The Steel Glass". He died in October 1577.

In 1572 appeared Gascoigne's "A Hundreth Sundrie Flowers". This was a miscellaneous collection of his poems, lyrical in part, and it was included in the enlarged edition of his works in 1575, called the "Posies of George Gascoigne Esquire".

The "Hundreth Sundrie Flowers" gave offense, Gascoigne himself tells us, first by reason of "sundrie wanton speeches and lascivious phrases" and, secondly, by "doubtful construction and scandal". The author professed that he had amended these defects in the edition of 1575. A comparison of the two texts shows that only a few poems were omitted. (2) tures of Master F. J." were left out. It must have been the prose tale which gave the chief offense. Gascoigne protested "that there is no living creature touched or to be noted thereby". (3) According to G. T. "it was the first beginning of his writings, as then he was no writer of any long continuance". (4) The story apparently recounts an

(1)

Cunliffe, J. W.- Works of Gascoigne-Vol. I, page 3.

(2) Ibid- Pages $\overline{500-2}$

(3) Ibid- Page 7

(4) Ibid- Page 495 
intrigue of Gascoigne's youth, as "Dan Bartholmew of Bath" one of his "middle age".

A very characteristic "Epistle to the Reverend Divines" gave five reasons for the publication of the poems, which were as follows: (1) Poetry is an excellent quality; (2) "I have", he says, "always been of opinion that it is not impossible, either in poems or in prose, to write both compendiously and perfectly in our English tongue"; he seeks advancement by virtue, and desires that his poetry may remain on record in token of the gifts with which it had pleased God to endow him; (4) there is more good than bad mingled with his writing; (5) his writing may serve as a mirror to unbridled youth( 1 ).

Let us glance at some of the poems of Gascoigne. In his lyric motives he shows the fondness for unusual and striking situations. His method seems to be to take over the titles and imagery of familiar themes into unrelated fields of emotion, so as to create, for each poem so treated, an artificial interest. For example, in the "Divorce of a Lover", the connotation of the title is the basis for a contrast with the real theme, as announced in the first line:"Divorce me nowe, good death, from love and lingering Life." So in the "Lullabie of a Lover", the poet, through the imagery of the slumber-song, bids farewell to youth and its pleasures:

"First lullaby my youthfull yeares, It is now time to go to bed", etc.

(1) Cunliffe, J.W.- Op. cit. Pages 2-8. 
The moral strain indicated in the subjects of the "Divorce of a Lover", and the"Lullabie", serves as inspiration for the two religious lyrics, "Gascoigne's Good-morrow" and "Gascoigne's Good-night". Slightly fantastic in imagery but devout and meditative in spirit, they seem nearer to Herbert then to the old moralizing poems.

Gascoigne has several poems of a spiritual nature. The best of these is his "De Profundis". The poem was written toward the end of his life (1577), and though the basis for his subject matter is found in the psalm bearing that name-- psalm 130-- it is but a retractation or repentance for his early life. It has all the violent and excessive emotion characteristic of the early Elizabethan religious verse:

"O gracious God, to thee I cry and yell; My God, my Lord, my lovely Lord, alone, To thee I call, to thee I make my moan."

These lines seem particularly ungentle and harsh, but again the influence of the courtly love system with the "fire of love" convention is seen. "De Profundis" opens with an appeal for mercy for past sin, especially before the Day of Judgment shall come. Then after a desire for the union of the poet's soul with the Infinite, he seems quite willing and eager to grasp at his share of the promise of mercy offered to all; and then at last, at peace, with God and his own heart, he awaits the visit of death. His autobiographical poem, "Dan Bartholmew of Bath", 
records the love adventures through which the poet passed during his early life. Considering the manner in which he spent his time at the Middle Temple and Gray's Inn, we are not surprised that his father disinherited him. The last stanza but three makes the personal character of the poem obvious:

"Well since my borrell braine is all to bloont To give a gesse what ende this man shall have, And since he rageth not as he was woont, Although sometimes he seeme (alite) to crave, Yet will I not his doings so deprave, As for to judge (before I see his ende)

What harder happe his angrie starres can sende". And this is probably one of the "slanderous Pasquelles against divers personnes of great callinge" laid to his charge in the petition which, in May, 1572, prevented him from taking his seat in Parliament: "He is a common Rymer and a deviser of slanderous Pasquelles against divers personnes of greate callinge". "He is a notorious Ruffianne and especiallie note to be bothe a Spie, an Atheist and Godles personne".

"Certayne notes of Instruction concerning the making of verse or rhyme in English", appended to the edition of 1575, marks, perhaps, the division between his amateur and his professional career. He now directed his literary

(1) Cambridge History of English Literature-Vol.III, page 230 
activity to the two ends of winning powerful patronage and establishing himself in public esteem. He was employed by Leicester in this same year, 1575, to furnish complimentary verses to the queen on her famous visit to Kenilworth castle.

As Gascoigne grew older he became steadier. Though he hardly attained the dignity of a literary artist, he succeeded in laying aside the frivolity of his youth and became a portentous moralist. Two serious efforts in prose were written toward the end of his life - the fruites of repentance" Gascoigne called them - entitled respectively "The Dromme of Doomesday" and "A delicate Diet for Daintie mouthde Droonkardes". In the dedication of the latter, dated August 10, 1576, he contrasted the wanton poems of his youth with the serious works of his maturity: my wanton Poesies, presumed fyrst to peark abroade, they came forth sooner then I wished, and muche before they deserved to be lyked...- And to make amendes for the lost time which I misbestowed in wryting so wantonlie: I have of latter dayes used al my travaile in matters both serious and Morall--These works or Pamphlets, I esteeme both Morall and Godly".

His sense of the vanity of human things is marked in all his later works. The ageing author had become pious and moral. (2) In April 1576 he published the poem by which he is best known, "The Steel Glass", a moral satire, conceived in

(1) Cunliffe, J. W.-Works of Gascoigne-Vol.II, page 453.

(2) Legouis, Fmile- History of English Literature-Vol.I, page 147. 
the spirit of Wyatt, but largely inspired by Langland's "Vision of Piers the Plowman". (1) This satire compares the truthful metal mirror of older days with the too flattering glass, doubtless of Venetian crystal, used by the gallants and ladies of the poet's time. Here Gascoigne denounces the profanity and luxury of modern manners. Describing the tastes and amusements of contemporary society he exclaims:

"O crystal glass, thou settest things to show Which are, God knoweth, of little worth indeed. And few behold by contemplation The joys of heaven, ne yet the pains of hell; Few look to law, but all men gaze on lust."

"There is something zestful in finding an aristocrat and courtier, scolding his class in a stinging satire, which happens to be the first of its kind in English literature. There was a spirit-stirring quality in the air in those early Elizabethan days that told in restless lives, that found joy in adventure and solace in singing the sweetest carols we possess". (2)

"The Steel Glass" reflects in the most vivid manner both the continuity of the reforming movement in religion, which had been supported by Wycliffe and Langland in the fourteenth century, and the active operation of the individual conscience in men, which was the great agent in the Reformation of the sixteenth century. This influence shows itself in the same year as "The Steel Glass", and

(1) Courthope, W. J.- Vol. II- page 173.

(2) Leigh, 0. H. - English Belles-Lettres-page 82. 
entitled "The Doome of Domesday" and "Delicate Diet for Dainty mouthed Droonkards". It also appears in his last poem, "The Grief of Joy", a satire on the vanity of man's Iife. (1)

Gascoigne's sole original comedy, the "Glasse of Government", which vaguely embodies some local knowledge acquired by the author in the Low Countries, seems to be "an attempt to connect Terentian situations with a Christian moral". (2) It deals with the careers of four youths, two prodigals who reach bad ends, and two of exemplary virtue, who gain distinction and influence. "This comedy, the first fruits of the 'regeneration' of the once worldly poet, has enjoyed only a 'succe's d' estime' in comparison with either 'The Steel Glass' which adorns a later stage of repentance, or his juvenile and rather frivolous 'Posies' ".

In summing up the merits and characteristics of this writer, let me say again that, on the whole, Gascoigne is a thoroughly Elizabethan figure. His moralizing and his immoralism were doubtless equally spontaneous; yet he helped forward both drama and poetry, whatever he did for religion; and it was in keeping with the standards of the time that after his early death in 1577 he should be credited by his literary friend, George Whetstone, with a "wellemployed life and godly end". In any case, he challenged our attention in that he was nearer the Elizabethan average

(1) Courthope, W. J.- Vol II, page 177.

(2) Herford, C. H.-Literary Relations of England and Germany

(3) Herford, C. H. - Page 150. in 16 th Century- page 150 . 
than better men and better poets.

The recent trend of criticism has been in Gascoigne's favor. His poems give the impression of a distinct, though not altogether pleasing personality. He is the "homme moyen sensuel" of the time, with added touches of reckless debauchery in his youth, and of too insistent puritanism in his later days of ill health and repentance.

It is extremely difficult to define the nature of the repentance or retractation found in the poetry. of George Gascoigne. It is not a Bunyan-like repentance, or extreme grief over venial sins. Neither is it the confession of a truly conscious and serious artist, as we found in the case of Spenser. Far be the retractation of this writer from the firm religious conviction expressed in the religious works of Donne. How then shall we come to a conclusion as regards the sincerity of the literary repentance of Gascoigne? Permit me here to advance my own theory. Gascoigne's sorrow over the influence of his sinful "Posies" was the direct outcome of the tense religious and moral strain due to the influence of stern puritanism. In the early Elizabethan age a writer was looked upon with much contempt, and his poetry was often thought to be dangerous and extremely defiling to the minds of the saintly Puritans. As we said in the beginning, Gascoigne was a transition writer. He was a pioneer, and, as a pioneer, he must be judged. I do not mean to imply that Gascoigne's change from the sensual to heavenly desires and aspirations was not sincere. These confessions came from 
the soul of the man who, late in life, found earthly pleasures of no avail and turned to heavenly things. To sum up this writer briefly, one might truthfully say that he was a "child of his age". 
ROBERT GREENE 


\section{ROBERT GREENE}

\section{"Robert Greene represents the Elizabethan age at}

its best and worst. What was best in it he helped to consummate. Of the worst he was the victim as well as the exemplar".

Greene was a true Elizabethan Englishman, impulsive, reckless, with a roving instinct that in many a life of that ruthless age found a safe vent in adventure on the sea. His writings give vivid pictures of life in the Elizabethan age, and at the same time form a most interesting autobiography of that "wretched life". Unlike Herrick, who could say that if his verse were impure his life was chaste, Greene's writings show scarcely any of the uncleanness so prevalent in books of that period.

It is easy to condemn Greene, impossible not to love him, important to understand him, for his is a typical figure. He may be taken as the epitome of many writers of the time, wild, profligate Bohemians in their lives, and in their writings earnest and often terrible moralists.

"Why should art answer for the infirmities of manners?" asks Thomas Nash in defending the memory of Greene against the attacks of Gabriel Harvey and other enemies. Some such consideration as this is needed when we study the works of Robert Greene. It has been the misfortune of the man to be remembered by posterity chiefly through adverse personal

(1) Dickinson, T. H.- Works of Robert Greene-page 10.

(2) Dickinson, T. H. - page 7. 
documents. Greene had been dead but a. short time when the pen of Gabriel Harvey endeavored to blacken his memory in "Foure Letters", the fierce malignity of which has thrown an indelible stain upon the character of its author. And to complete the tale of disfavor, Greene himself tells his own story with "a morbid self-consciousness only exceeding Bunyan's, and a thrifty purpose to turn even his sins to pence". (1) Like many another author, Greene no doubt exaggerated his sins and this has given rise to.a probably too harsh estimate of the poet's failings.

Though during Greene's life and after his death circumstances were unmeet to dispassionate biography, it may promote the calmer mood of a later age to inquire into the conditions of his disordered career and the sources of his unique genius. "Debt and deady sin, who is not subject to?" cries Nash. "With any notorious crime I never knew him tainted". (2) natural frailty made Greene what he came to be. Had his youth escaped the contamination of Italian vices, had his abilities been recognised by society, or had a place among men of education and good manners been open to his cholce, he might perhaps have prospered. There were two separate selves in him, and they proved incompatible, and somewhat "bourgeois" tendencies, highly appreciating honor, respect-

(1) Dickinson, T. H.- Works of Greene-page 9.

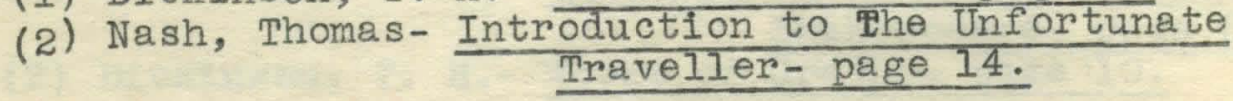


ability, decorum, civic and patriotic duties. Greene's other self was not, properly speaking, the counter-part of the first, and had no taste for vice as vices, nor for disorder as disorder, but was wholly and solely bent upon enjoyment whatever be the sort, the cause or the consequence. Hence the glaring discrepancies in Greene's life, his faults, not to say his crimes, his sudden short-lived repentances, his supplications to his friends not to imitate his example, his incapacity to follow steadily one course or the other. "His better self kept his writings free from vice, but was powerless to control his conduct". And of truth he must be represented as no isolated figure, but as a man of his times, frail, no doubt, but "frail.with Marlowe and Peele, versatile with Sidney and Raleigh, reflective with Spenser, and lusty with Shakespeare". (2)

The sources of our knowledge and deduction concerning Greene's life are of four classes- records, autobiographical pamphlets and allusions, contemporary references, legends. For the purposes of this paper we are concerned chiefly with his autobiographical pamphlets and allusions. To this class of biographical materials belong Greene's own proșe works, the "Mourning Garment", "Never too Late", the "Groatsworth of Wit", all partly autobiographical; and"The Repentance of Robert Greene", confessedly autobiographical.

(1) Jusserand, J. J.- The English Novel in the Time of

(2) Dickinson, T. H.- Works of Greene-page 10. 
At this time a short sketch of his life will be helpful in our effort to understand the nature of Greene's confessions.

Robert Greene was a native of Norwich. We learn this fact from a passage in "The Repentance of Robert Greene": "I need not make long discourse of my parents, who for their gravitie and honest life are well knowne and esteemed amongst their neighbors; namely, in the cittie of Norwitch, where I was bred and born". (1) The date of his birth has - not been ascertained; in all probability it may be fixed about the year 1560. He was educated at Cambridge, taking the degree of A.B. at St. John's College in 1578 and that of M.A. at Clarehall in 1583. During the time that elapsed between his taking the degree of A.B. and that of M.A., Greene visited Italy, Spain, and other parts of the continent. In his "Repentance" he says: "For being at the Universitie of Cambridge, I light amongst wags as lewd as myselfe, with whom I consumed the flower of my youth; who drew me to travell into Italy and Spaine, in which places I sawe and practizde such villainie as is abhominable to declare-- At my return into England, I proceeded Maister of Arts". Upon his return home he is supposed to have taken orders and received the living of Tollesbury in Essex. Early biographers, among whom was Dyce, attempted to show that at one time Greene was a minister. Dickinson does not agree.

(1) Repentance of Robt. Greene- Edited by G. B. Harrison,page19.

(2) The Repentance of Greene- page 19.

(3) Dickinson, T. H.- Robert Greene- page 23. 
He thinks that Greene was never connected with the vicarage of Tollesbury.

Attempting to barely outline the remainder of Greene's life, one might say that he married not later than 1585, lived with his wife until the birth of a child, in 1586 deserted her, and went to London never to return. There undertaking the composition of serious plays, he continued a high and loose course of living, writing love pamphlets until about 1590, and then, in obedience to a promise repeatedly made by himself, pressing forward the exposure of devices used by cozeners and conny-catbhers, until his career was cut short, by an illness resulting from"a surfeit of pickled herring and Rhenish wine", on Sept. 3, 1592. Deserted by his friends, he died in extreme poverty at the house of a poor shoemaker who had befriended him.

Greene's autobiographical work begins in his "Mourning Garment" (1590) and "Never too Late" (1590). He does not, as yet, deal directly with London life, though his own experiences, lightly velled, form the nucleus of the tales. "The Mourning Garment" is a modernised version of the prodigal son story, with the addition of pastoral details as reminders of his earlier craft. In "Never too Late" the author's career is more closely followed. In this there is recounted the fortunes of "a gentleman of an ancient house, called Francesco; a man whose parentage though it were worshipful, yet it was not induced with much wealth;

(1) Allibone- Dictionary of Authors-Vol.I- page 7336 
insomuch that his learning was better than his revenues, and his wit more beneficial than his substance". That Greene has described some of his own adventures under those of Francesco in his "Never too Late" must be, I think, sufficiently evident to everyone who has perused it with attention.

"Never too Late" and other prose works of Greene are interspersed with verses which are composed in that ornamental and figurative style which is akin to poetry, and which lllustrate the repentant state of the poet's mind. I quote here "Francesco's Sonnet, made in the prime of his penance":

"With sweating brows I long have plough'd the sands; My seed was youth, my crop was endless care; Repent hath sent me home with empty hands At last, to tell how rife our follies are; And time hath left experience to approve, The gain is grief to those that traffic love.

The silent thoughts of my repentant years, That fill my head, have called me home at last; Now Love unmask'd a wanton wretch appears, Begot by guileful thought with over-haste; In prime of youth a rose, in age a weed, That for a minute's joy pays endless need. 
Dead to delights, a foe to fond concelt, Allied to wit by want and sorrow bought, Farewell, fond youth, long foster'd in deceit; Forgive me, time, disguis'd in idle thought; And love, adieu: 1o, hasting to mine end, I find no time too late for to amend!"

In 1592 further autobiographical work was penned by Greene on his deathbed, when the veil concealing the author's identity is deliberately lifted. The main facts of his life are dealt with, and in the "Groatsworth of Wit" he deplores his fate, earnestly warns his comrades, and gives a melancholy picture of Elizabethan literary Bohemianism.

The story told in the "Groatsworth of Wit" closely resembles that of "Never too Late" and is clearly autobiographical. That he intended Roberto for apicture of himself, he has not left us to doubt. Near the end of the story, he writes: "Heere, gentlemen, break I off Roberto's speech, whose life in most part agreeing with mine, found one self punishment as I have done. Hereafter suppose me the said Roberto, and I will go on with that he promised". The character and miserable end of Roberto as a result of the profession he had assumed may be given in Greene's own words: For now when the number of deceits caused Roberto to be hateful almost to all men, his immeasurable drinking had made him the perfect image of the dropsy, and the loathsome scourge of dust tyrannised in his bones.-.- This miserable 
man lay comfortlessly languishing, having but one groat left, which looking on, he cried, ' 0 , now it is too late, too late to buy with thee; and therefore will I see if I can sell to careless youth what I negligently forgot to buyAnd though no man now be by to doe me good, yet, ere I die, I will by my repentance indevor to doe all men good! " Greene, in the very striking and impressive address to his brother play-wrights, with which he concludes his "Groatsworth of Wit", laments his failures and repents of his sins: "Delight not (as I have done) in irregular oathes; for from the blasphemers house, a curse shall not depart. Despise drunkenness, which wasteth the wit, and maketh all men equall unto beasts. Flie lust, as the deathsman of the souls, and defile not the Temple of the Holy Ghost. Abhorre those Epicures, whose loose life hath made religion lothsome to your eares; and when they sooth you with tearms of Maistership, remember Robert Greene, whome they have often so flattered, perishes now for want of comfort".

$$
\text { In the following line he expresses contempt for the }
$$
world and for worldly things:

"Deceiving world, that with alluring toyes, Hast made my life the subject of thy scorne: And scornest now to lend thy fading joyes, To length my life, whom friends have left forlorne, One never see thy sleights, which few men shun, Till unawares they helpelesse are undone".

(1) Groatsworth of Wit- Harrison-page 47. 
"O that a year were granted me to live, And for that yeare my former wits restorde: What rules of life, what counsell would I give? How should my sin with sorrow be deplorde? But I must.die of every man abhorde. Time loosely spent will not again be wonne, My time is loosely spent, and I undone".

The utterances of "Roberto" over the husks on which in the last period of his career he was prone enough to moralize, must from a biographical point of view be taken for what they are worth. "But the want of tone which they attest is observable in his earlier, even more than in his later, writings; for until he becomes sorry for himself, he has, in point of fact, nothing very particular to say".(2) Since Greene, in both "Never too late" and in "A Groatsworth of Wit", has undoubtedly exaggerated the incidents and heightened the coloring much beyond the truth, it is very difficult to determine what portions of them are to be received as facts. One may set down as autobiographical whatever portions of those pieces he may think proper. These two pieces may be regarded as among the best of Greene's pamphlets. They serve not only as illustrations of his life, but as specimens of his style in prose.

To a somewhat different class of testimony belongs

(1) Groatsworth of Wit- Edited by Harrison- pages 39-40.

(2) Craik- English Prose-Vol.I,-page 552. 
"The Repentance of Robert Greene", probably an "authentic exemplar of that very popular class of death-bed repentance that was multiplied by other hands after Greene's death". Its style, is, perhaps, inferior to that of his earlier work, and the writer seems intent on painting his life in the most sombre colors. Little can be found in this work but admonitions to a higher life and caveats against lust.

In the preface, Greene addresses the wanton youths of England in the following words: "When I consider, (kinde Cuntrimen), that youth is like to the spring time of mans age readie in the bloome to be nipped with everie misfortune, and that a young man is like to a tender plant, apt to be wrested by nurture either to good or evill, as his friendes like good Gardeners shall with care indevour his education, seeing in the prime of our yeares vice is most ready to creep in, and that want of experience committeth sundrie wanton desires, I thought good to lay before you a president of such prejudiciall inconveniences, which at the first seeming sweete unto youth, at the last growe into fruits of bitter repentance". (2)

Greene tells us that once he felt a terror of God's judgment: "I felt a feare and horrour in my conscience, and then the terrour of God's judgments did manifestly teach me that my life was bad, that by sin I deserved damnation, and that such was the greatness of my sinne that I deserved no
(1) Dickinson, T. H. - Robert Greene- page 20.
(2) Repentance of Robt. Greene- Edited by Harrison- page 5. 
redemption". This followed a lecture by a "godly learned man". In St. Andrew's Church in the city of Norwich. But when his companions fell upon him, in a jesting manner calling him Puritan and precisian, and wished he might have a pulpit, what he had learned went quite out of his remembrance. "So that I fel againe with the dog to my olde vomit, and put my wicked life in practise, and that so thoroughly as ever I did before".

Enough has been quoted, sufficient examples of Greene's confessions have been given to show that the author repented of his sins and looseness of life. Now it is out task to determine the nature of his repentance.

The question of Greene's sincerity arises especially in connection with his "Confessions", the last in date of his prose works. Worn out by debauchery and poverty, he brought out one after the other, several pamphlets filled from end to end with sorrowful self-accusation. In there he avers his own conversion and deplores his errors, but this intemperate conversion involves the accusation of the companlons of his debauchery, George Peele, Nash, and Marlowe, whom, without any scruple for implicating them, he apostrophises. Repentance for their atheism, lusts and blasphemies mingles with his remorse for his own back slidings, and he adjures them to be converted too. "He must have been a drunkard to the end, for vinous tears have certainly watered the ink with which he pens these pages". "The most famous

(1) Legouis-History of English Literature-Vol.I- page 219. 
passage is that in which the popular theatre hack denounces a new playwright who once dressed himself out in borrowed plumes, taken from Greene and his friends, but now can do without them. Here we have the first evidence of Shakespeare, the actor-author. At the thought of his rivalry, Greene's complaints are turned to fury, and he forgets that he is speaking of the very vanities which elsewhere he declares himself to outlived and exhorts his former boon-companions to abandon.

Greene's life was one of struggle and drift, a wayward course of frustrated good intentions; and these things left their impress upon what he wrote, and upon his manner of writing. It is surprising to see how polished and how finished some of his pieces are, when it is considered that he wrote most of them to supply his immediate necessities, and In quick succession to one another. Wild as was the life of Greene, his pen was pure. At heart he was an idyllist, and his eupheristic romances are on as high a moral plane as Iyly's. His work is free from licentiousness; he never "gave the looser cause to laugh."

Greene was an impulsive sort of person, readily kindled to generosity, or carried by sympathy or ridicule into vice, and above all filled with that artistic instinct which compelled him to give expression in poetic or literary form to what he felt and knew. He gave himself up to all pleasures, publicly with tears confessing his vices, and the next moment plunging into them again. "You see the pure man is candid, 
not sparing himself; he is natural; passionate in everything, repentance or otherwise; eminently inconstant, made for self-contradiction not self-correction".

Dickinson thinks that the didactive motive is the one which inspired Greene in all his works. "When Greene began to write, art was not yet strong enough to command a popular hearing without the assistance of a didactive motive. Adopting himself to the conditions with a tact that made him the most broadly read writer of his time, Greene made edification the end of his writings from the first". points out that Greene's second work to be entered on the Stationers' Register, March 1581, had a distinct moral purpose, and that throughout the poet's life, moral purpose remained a factor in his prose and drama. Even the Palmer who tells the tale of "Never too Late" is himself penitent for his past sins. In "Friar Bacon and Friar Bungay" the jolly friar is made at the end to surrender his calling through motive of remorse as far as possible from the spirit of his life, and "James IV"ends with the penitent sovereign begging forgiveness for his sins. Dickinson says these facts show, if they show anything, that the motive of repentance was a conventional thing with Greene, and that however faithful it may have been to his own experience not the least advantage in its use lay in its popularity. Repentance may have been a conventional thing with

(1) Taine- History of English Iiterature-Vol.I, page 236. (2) Dickinson, T. H.- Robert Greene-Page 16. 
Greene. But if I may make my own estimate of this writer's confessions I must needs go deeper than merely to state that repentance was conventional with him.

What made repentance the general theme of Greene's writings? Not the sole, selfish desire to sell what he wrote. To be sure, Greene had to make his living by the fruit of his pen; but I think another deeper and more profound motive inspired him. His life full of recklessness and sin was never well-rounded and normal. He felt the sting of a stricken conscience, the deep remorse for his wasted life. His intellect, though very keen and active, was swayed by the conflicting influences of good and bad. To act one minute and then repent the next! This process repeated over and over again would weaken the strongest will power and the firmest consciences.

To sum it up in a word, the ruin that overwhelmed him was the fate of many poets of great mind and weak will. He sought consolation and repose in art when life could offer him nothing but sin, sorrow and disappointment. I like to think that poets are sensitive souls, and that beneath the desire for personal gain and edification, there is true devotion to the art which brings people a little nearer to the beautiful, noble and sublime. In Greene's life there was a conflict between the fresh, unworn sense of beauty and poetry, and the bitter, disillusioned cynicism of premature old age. 
Greene was a true Elizabethan. He was true to his time in the vastness of his conception and in the narrowness of his life, in his poetic triumphs no less than in his personal defeats. The marvellous thing is that in the midst of riotous life he should have learned repose in art, that though writing in a tavern his muse should have remained chaste. 

THOMAS NASH.

Thomas Nash (1567-1601) claims a place of no little importance in the history of English prose.

Nash was the real successor of Greene, the realist and satirist. Like his friend Greene, Nash was responsible, in the first place, for certain pamphlets dealing with the social life of London; but he does not confine himself, as was the case with Greene, to the outcast, nor, on the other hand, does he find much attraction in the steady-going citizen. His attack is directed against respectable roguery, against foolish affectations and empty superstition; and these things proved excellent whetstones for his satirical wit. He satirised contemporary society and all whom he believed to be impostors with effusive vigour and frankness. Nash was an author by profession -- careless, jovial and dissipated -- alternating between riotous excess and abject misery; but he was generally in want. He was one of those men, full or spirit, fire and imagination who fancied they could live by their pen, and who died prematureIy and miserably.

The history of Nash, "a son of the manse", bears a strong resemblance to that of Greene.

The son of a Suffolk minister, Nash was born at Lowestoft in 1567, and matriculated at St. John's College, Cambridge, on 0ct. 13, 1582. The larger life beckoned him, 
and he left Cambridge for London. There he made some figure in literary circles, wrote prefaces to Greene's "Menaphon" and Sidney's "Astrophel and Stella", completed Marlowe's "Dido", and produced some plays of his own, took a hand on the bishop's side in the Martin Narprelate controversy, engaged in a notable pamphlet war with Gabriel Harvey, and wrote a few satirical prose pieces, some lyrics, and a realistic novel. In 1601 there appeared in Charles Fitzgeffrey's "Affaniae" a Latin epigram on Nash's death. When he died, or when, or how, we do not know.

Detesting Puritanism, probably out of reaction against his father's strictness, he took the anti-Puritan side in the Martin Marprelate controversy. His irritable mood was exasperated by poverty and the sense of wrong operäting upon an abnomal self-esteem. In the most remarkable of his tracts, "Pierce Penniless his Supplication to the Devil" (1592), he proclaims himself to the world as Pierce Penniless, and, on a retrospect of his literary life, observes: "Having spent many years in studying how to live, and lived a long time without money; Having tired my youth with folly, and surfeited my mind with vanity, I began at length to look back to repentance, and address my endeavours to prosperity. But all in vain; I sat up late and rose earIy, contended with the cold and conversed with scarcity; for all my labours turned to loss, my vulgar muse was de-

(1) Brett-Smith- Preface to "Unfortunate Traveller"-page 5. 
spised and neglected, my pains not regarded, or slightly rewarded, and I myself in prime of my best wit laid open to poverty". (1)

Such was the miserable cry of an "author by profession" in the reign of Elizabeth. Although he lived in this great age of Elizabethan literature, he writes as if he had lived in our own. (2)

Nash reviewed the manners, the absurdities and the superstitions of his day in the "Anatomie of Absurditie" (1589), "Pierce Penniless" (1592), "Christ's Teares over Jerusalem" (1593), and the "Terrors of the Night" (1594). - For purposes of this study, we are concerned, for the most part, with "Christ's Teares over Jerusalem", in which the author confesses the errors of his past life and retracts his opinions.

After his many controversies Nash grew troubled by religious doubts; his temper took a pacific turn, and he endeavored to make amends to, and peace with, Gabriel Har(3) vey. On sept. 8, 1593 he obtained a license for publishing a series of repentant reflections on the sins of himself and his Iondon neighbours, called "Christ's Teares over Jerusalem". The dedication is addressed to Elizabeth, wife of Sir George Carey. Nash admits that he had carried his (4) literary warfares to excess:

A hundred unfortunate

(1) Shakespeare Society Pub. (1842)- Pierce Penniless-page 5.

(2) Disratie, Isaac- Calamities and Quarrels of Authors, V01. I, page 39

(3) Lee, Sir Sidney-Dictionary Nat' I Biography, Vol.XI, page 105.

(4) Grosart, A. B.- Works of Nash-Vol. IV, page 15. 
farewels to fantasticall satirisme. In those vaines heretofore I misspent my spirit and prodigally conspired against good houres. Nothing is there now so much in my vowes as to be at peace with all men and make submissive amends where I have most displeased."

Nash plainly states his repentance. "Many things have I vainly sette forth, whereof it now repenteth me. St Augustine writ a whole booke of his Retrotractations. Nothing so much do I retract, as that wherein soever I scandalized the meanest. Into some spleanative vaines of wantonnesse, heretofore have I foolishlie relapsed, to supply my private wants: of them no lesse doe I desire to be absolved then the rest, and to God and man doe I promise an unfained conversion." (1)

Declaring himself tired of the controversy with Harvey, Nash acknowledged in generous terms that he had rashly assailed Harvey's fame. But Harvey was deaf to the appeal. The offer was most ungraciously and ungenerously rejected by the latter in his"Hew Letter of Notable Contents" (1593). The battle was at once renewed. In a second edition of his "Christ's Teares" Nash accordingly withdrew his offer of peace and lashed Harvey anew with unbounded fury. Nash's plous strains were popular; his "Christ's Teares over Jerusalem" went through three editions, in 1593, 1694 , and 1613.

(1) Grosart, A. B.- Works of Nash-Vol. IV- page 16. 
This work is one of those rather enigmatical expressions of repentance for loose life which were so common at the time, and which, according to the charity of the reader, may be "attributed to real feeling, to a temporary access of 'Katzen-jammer', or to downright hypocrisy, bent

- only on manufacturing profitable 'copy' and varying its style to catch different tastes".

Another example of the repentant attitude of Thomas Nash is found in one of a group of poems inserted in Nash's edition of "Atrophel and Stella". "The lines are not much in themselves, but the existence of them has never been hinted at by any of the biographers of Nash, nor by a single bibliographical antiquary".

"If floods of teares could clense my follies past, And smokes of sighes might sacrifice for $\sin$; If groning cries might solve my fault at last, or endles mone for error pardon win;

Then would I crie, weepe, sigh, and ever mone Mine error, fault, sins, follies, past and gone".

In all things Nash was a literary Bohemian born out of due time. His choice of subjects, his delight in the compounding of word or phrase, his instinctive hatred of Puritans and adoration of poetry, all bear witness to his artistic temper.

The apology for his own life and Greene's is: "Debt

(1) Saintsbury, G.-History of English Literature, Vol.II, page 234.

(2) Shakespeare society Pub.(1842)- Pierce Penniless-page 21. 
and deadly sinne, who is not subject to? With any notorious crime I never knew him tainted". (1) These, of all Nash's words, are those that give the most vivid picture of the man; it was no saint who wrote "The Choice of Valentines", but a very human sinner, and on those words the man himself must be judged. He does not live in our daily life as Chaucer does; he is too quick to anger, and lacks his divine tolerance; but he is a figure little less distinct than his own portrait of Greene, a minor man of letters, but an inquiring connoisseur of life. (2)

If I may make my own estimate of the nature of Nash's repentance, let me say, first of all, that from the religious point of view I do not think that he was sincere in his manifestations of regret over the sins of his past life.

However, this attitude does not signify that I condemn the repentance of Nash. I certainly do not. Many things have to be considered when one studies the literary productions of an early Elizabethan writer. "An author at this age was much like a vagrant". (3) the fruits of his pen. Harrassed by the many who condemned literary work, dragged down by poverty and misfortune, Nash had to resort to various devices to make an appeal to the public. He was a wit; he depended on inspirations, fire, enthusiasm. I think Nash realized he had gone too far in

(1) Nash, Thomas - Introduction to"the Unfortunate Traveller",page 14

(2) Brett-Smith-Preface to"Unfortunate Traveller", page 15.

(3) Disraeli, Isaac- Calamities and Quarrels of Authors-page 45. 
his controversy with Gabriel Harvey and wished to make amends for past follies. Like the typical Elizabethan of his day he bursts forth in a moment of intense passion, only to repent of it as soon as he feels remorse of conscience.

Nash's literary dependencies were various, though in the main he was the natural product of the life of his day. He was one of a group of university wits who had accumulated the materials of scholarship interests and who were yet confronted with the serious problem of getting a living out of their university training. Such scholars were readily drawn into the whirlpool of London life, where they only too often sacrificed not only their scholarship, but all sense of decency and morality to a false notion of genius. "Yet Nash, child of his age though he was, manifestly falls in line with a long established English tradition. He takes his place with the ancient ranting and ralling masters of eloquence, of whom examples are to be found as far back as Piers Plowman". (1)

(I) Krapp, G. D.- Rise of English Literary Prose-page 483. 
EDMUND SPENSER 
SPENSER'S "FOWRE HYMNES".

In this treatise I shall attempt to discuss Spenser's "Fowre Hymnes" as an instance of "Formal Retractation" or "Literary Repentance".

In September 1596, only two years before his flight from Ireland and, less than three years before his death, Spenser wrote a sensitive and courtly epistle dedicatory for his "Hymnes" to the right honorable and most vertuous Ladies, the Ladie Margaret Countess of Cumberland, and the Ladie Anne Countess of Warwicke".

The first two hymns were written, he tells us, "in the greener times of my youth", probably in the days when as a shepherd poet he wooed Rosalind; or as many scholars interpret, the Cambridge period, or about 1570-80. And it may reasonably be concluded that they were among the earliest of his surviving works.

Many critics have puzzled over the poet's stern condemnation of these earlier hymns which, Spenser says, "too much pleased those of like age and disposition, which, being too vehemently carled with that kind of affection, do rather sucke out poyson to their strong passion, then hony to their honest delight". Spenser also tells us that he was moved by one of "you two most excellent Ladies, to call in the same". The poet, unable to recall completely these amorous 
lyrics, "by reason that many copies were formerly scattered abroad", put them forth with two new poems, "An Hymne of Heavenly Love" and "An Hymne of Heavenly Beautie", in the first of which he writes:

"Many lewd layes (ah woe is me the more!)

In praise of that mad fit which fooles call love,

I have in th' heat of youth made heretofore

That in light wits did loose affection move. But all those follies now I do reprove, And turned. have the tenor of my string, The heavenly prayses of true love to sing".

What is there in the first two hymns that one might call "lewd"? In our modern sense of the word there is nothing. Then what was it that could have offended one of these noble ladies? Spenser tells us that one of these two ladies advised that the hymns in praise of Love and Beauty should be suppressed as being too warm in their tone. A precisian she must have been.

Who were these noble ladies to whom Spenser dedicated his hymns? Let us glance for a moment at the family from which they came. Lady Margaret Countess of Cumberland and Lady Anne Countess of Warwick were daughters of Francis Russell, second Earl of Bedford (1527-85). (2) came to the throne, Bedford was at once sworn to the privy council and took an active part in the religious settlement

(1) Hymne of Heavenly Love- lines 8-14.

(2) Dictionary of National Biography-Vol. XXVI. 
being one of those who assisted in the drawing up of the new liturgy. He was a very influential person and many books were dedicated to him, among them Cooper's "Chronicle", and Becon's "Christian Knight".

Margaret Countess of Cumberland was the youngest daughter of Sir Frances Russell. Her daughter describes her as "a woman of greate naturall wit and judgment, truly religious and virtuous". She was also a lady with sane pretension to literary tastes. A manuscript note in a Bodleian copy of Walpole's "Noble Authors" ascribes to her "some beautiful verses in the style of spenser".

Anne Russell married. Ambrose Dudley, Earl of Warwick. He was popularly known as the "Good Lord Warwick", and was attaches to the Puritans. He was governor of the possessions and revenues of the preachers of the gospel for Warwick(3) shire.

I think it was Anne Countess of Warwick who objected to the earlier hyms in praise of Love and Beauty. From the above account of the family of Lady Anne, we know that she belonged to a strict Puritan family. As a Puritan she would naturally protest against the very subject matter of these hyms "earthly or naturall love and beautie".

Just how close was the connection between Spenser and the Russell family we do not know. The friendship was no doubt brought about in the court circles and strengthened by

(1) Dictionary of National Biography - Vol. XV.

(2) Ibid.

(3) Dictionary of National Biography-Vol XVIII. 
the fact: that Spenser was closely associated with Robert Dudley, Earl of Leicester who was the brother-in-law of Anne Countess of Warwick. We do not know that Spenser dedicated the hymm to these noble ladies who, we believe, were stern Puritans. Higginson tells us that chief among those prominent in the State who favored the Puritans for personal convictions or for political reasons, and who gradually came to be recognized as their patrons, were the Earls of Leicester, Warwick, and Bedford. (1)

The next question that presents itself to us is: Was Spenser then, as many think, recoiling with a Bunyan-like repentance? I cannot think so if "Bunyah-like repentance" implies, as it generally does, the remorse of a large soul for venial sins. No, I believe that in "the judgment of the supreme court of the muses Spenser had sinned most grievously against that high seriousness with which he, in cormon with a very few poets, had been specially entrusted". Spenser was a sincere devotee of duty and right. His work is permeated with strong patriotism. He had enveloped himself with the refined atmosphere of Italian humanists and poets; yet as an anxious Protestant sympathizing at bottom with insular Anglo-Saxon moralists like Ascham and Cheke, he felt that his Italiante countrymen, of the oxfordOrmond-Hatton type, were open to the reproach of effemina cyr

(1) Higginson, J. F.-"Spenser's Shepherd's Calender"-page 17. (2) Cory's - Edmund Spenser-page 328. 
and corruption. They had listened to the siren songs of "Circe's Court".

In his day, the poet tells us, the very walls and windows of the English court were "writ all full of love, and love, my dear". The courtier's whole talk and study was of love. Though this love was in the use of many only an "idle name", "a compliment for courting vain"-- not keeping them from lewd speeches and licentious deeds-- it was nevertheless the result of a new acquaintance with philosophic thought on the subject developed in the south.

\section{(2)}

The subject of Platonism in Spenser might occupy us long. Ideas of Platonic love drawn from the "Courtier" are to be found in the "Hymms to Love and Beauty". These ideas are obviously not a natural fruit of French chivalry, but a graft from Greek philosophy. To him love was the "crown of knighthood", and he lingered joyfully over ancient tales in which, though simply, it was exhibited as such.

Though the Renaissance delighted in every expression of beauty, it especially revelled in that type which could hear and smell and touch and see -- sensuous beauty.

Claviere tells us that during the Renaissance there was delight in beauty of the nude which was admired by the ancient Greeks. He also tells us that Michelangelo proved the possibility of glorifying "the human figure fearlessly-unblushingly without weakening in any way the general concep-

(1) Schofield- Chivalry in English Literature-page 156.

(2) Schofield- Chivalry in English Literature- page 159.

(3) Fletcher, J. B.- Religion of Beauty in Woman- page 2. 
tion of vigour and chastity" (page 202). Platonist aesthetics is largely responsible for this attitude, for it taught "that the human body is the perfect type of terrestrial beauty, just as the human soul is the queen of the universe".

Moral laxity followed. The explanation is very clear. Morality passed from the restraint of the Middle Ages to the opposite extreme during the Renaissance. As Hulme, referring to the "wide range of expression, from superlative intellectual activity and artistic creation to the depths of pagan sensuality", explains: "The standards of intermal moral control had not yet been developed and those of external control had been discarded. It is this that produced such violent contrasts of emotion and conduct."

The Renaissance brought with it a joy of life such as had not been felt previously. "Sadness concealed itself, joy kept the whole world dancing to its 'merry pipe! "

The Puritans objected to such conditions of life. They first objected to discipline; later they became involved over doctrine; and finally they were distinguished as a definite social factor revolving about a strict and severe code of morality which developed into bigotry.

The University of Cambridge became the scene of sharp religious contention. During the seven years which Spenser spent there from May 1569 to June 1576, the University was persistently agitated by controversy between the Puritans

(1) Hulme- Renaissance and Reformation-page 71.

(2) Claviere- page 226. 
and Anglicans. Next to London it was the chief center of Puritan agitation.

A favorite opinion in recent years has been that Spenser was an extreme Puritan, presumably a Presbyterian at heart. He must have had some contact with the great Presbyterian leader of that day, Thomas Cartright, who returned to Cambridge as professor of divinity in 1569, the year that Spenser entered the University. The view that Spenser was an extreme Puritan is advocated by Winstanley and view. They hold that Spenser was not hostile to episcopacy, but that he favored a purified Anglicanism. I think that Spenser was a Low Churchman, that he always was a church Puritan, an earnest, zealous Low-Churchman.

Spenser's Puritanism was political and national, rather than religious. He went heartily with the Puritan party in their intense hatred of Rome and Roman partisans; he went with them also in their dennnciation of the scandals and abuses of the ecclesiastical government at home. But in temper of mind and intellectual bias he had little in cormon with the Puritans. For the stern austerities of Calvinism there could not be much sympathy in a man like Spenser. What then, was the purpose of the retractation found in the Preface to the "Fowre Hymnes"? I think the preceding

(1) Higginson, J. J.- Spenser's Shepherd's Calender-page 30.

(2) Winstanley-Modern Language Quarterly, Vol. III 6-16, 103-10.

(3) Higginson- Shepherd's Calender-pages 38-162.

(4) Church- Spenser-page 16. 
paragraphs on Puritan ideals of life largely explain Spenser's attitude.

A poet at this time still had to justify his employment by presenting himself in the character of a professed teacher of morality, with a purpose as definite and formal as the preacher in the pulpit. Even with this profession, he had to encounter many prejudices, and men of gravity and wisdom shook their heads at what they thought his idle trifling.

In earlier and later times men do not apologize for being poets; and Spenser himself was deceived in giving himself credit for this direct purpose to instruct, when he was really following the course marked out by his genius. But he only conformed to the curious utilitarian spirit which pervaded the literature of the time. Readers were supposed to look everywhere for a moral to be drawn, or a lesson to be inculcated, or some practical rules to be deduced; and they could not yet take in the idea that the exercise of the speculative and imaginative faculties may be its own end, and may have indirect influences and utilities even greater than if it was guided by a conscious intention to be edifying and instructive.

Once for all we must realize that we are dealing with a poet of the English Renaissance. "He is an artist in words in an age of foul smells and much foul talk". (2) His poetic

(1) Church- Spenser-page 86.

(2) Robertson, J. M.- English Literature- page 75. 
appetite for the beautiful and the picturesque had the better of his reason. He glorified in his verse what he detested as a sectarian. (1) Spenser said reason is enslaved to the appetites, it is the tool of fancy; sensual pleasures are no longer subordinated to the inward joys of contemplation. Habit and familiar language made it not strange that in the court of Elizabeth the most high-flown sentiments should be in every one's mouth about the sublimities and refinements of love, while everyone was busy with keen ambition and unscrupulous intrigue. (2)

Sometimes Spenser appears with a kind of "double self". At one time he speaks as one penetrated and inspired by the highest and purest ideas of love, and filled with aversion and scorn for the coarser forms of passion. At another, he puts forth his power to bring out its most dangerous aspects in highly colored pictures. The combination is not like anything modern, for both the elements are in spenser so unquestionably and simply genuine. But Spenser's words do not ring hollow. With a kind of unconsciousness and innocence, which we now find hard to understand, he passes from one standard of thought and feeling to another; and is quite as much in earnest when he is singing the pure joy of chastened affections, as he is when writing on "sensuous love and beauty". (3) Tardily, indeed, he seems to have acknow-
(1) Legonis, E.- Spenser-page 25.
(2) Church- Spenser- page 152.
(3) Church- Spenser-page 152. 
ledged the contradiction. At the instance of two noble ladies at the court, he composed his "Hymns of Heavenly Love and Beauty" to retract the two earlier ones composed in praise of earthly love and beauty.

We see then the two sides of Spenser's character. He is a fitting example of the combination of the two opposing forces of the time -- Renaissance ideals and stern Puritanical doctrine. These forces were always at work, and we find Spenser, the "religious and moral-minded writer" ever facing the two opposing issues.

\section{(2)}

J. B. Fletcher says that instead of retracting or suppressing them, Spenser gave the two dangerous hymns even wider circulation than before by publishing them, and thus ran some risk of being charged with insincerity. But one way of retracting, as he says, is to "amend" and "reform", and this spenser has done by rounding out in the third and fourth hymns, under the light of later spiritual experience, what, in the hymns written in youth, was necessarily incomplete, and in so far false as it was not the whole truth. "The sympathetic reader finds ultimately in the four hymns neither a contradiction nor a merely philosophical or theological document, but the confession of a profoundly sensitive and serious man, revealing the course of his spiritual development. It is a progress upwards from an early and ordinary disappointment in love, to ultimate intense consciousness of eternal things, indeed to an equivalent of

(1) Legonis- Edmund Spenser-page 25.

(2) Fletcher, J. B.- Pub. M. L. A. '26-page 453. 
the Beatific Vision itself".

Cory seems to think that Spenser revised the two earlier hymns when he published them along with the poems of Heavenly Love and Beauty. He says: "The youthful hymns which he probably revised as more earthly preludes to his God-seeking, though still tinged with the old febrile mood, must have been, too, from the first, noble with that love which he sought in Plato more ardently than any other English poet except Shelley".

I do not agree with Mr. Cory. I do not think Spenser revised or changed in any way the first two hymns in praise of earthly love and beauty. By publishing them side by side with the hymns of Heavenly Love and Beauty, Spenser sought to produce the effect upon the reader that only a striking contrast or antithesis can produce. As a moral man, as a conscientious poet, as a real artist, he sought to combine his renunciation of all that is sensuous and earthly with his praise of all that is pure and holy, in a truly artistic manner.

Spenser is to be regarded in the first place as a poet, and only secondarily as a moralist or philosopher. The nature of his allegory, pastoral or chivalrous, has to be taken into account, but only so far as it helped to determine the form and character of his compositions.

Much has been said as regards the question of retractation in the "Fowre Hymnes". Now I shall turn more specifically to the poetry of the hymns and endeavor to point out the passages of most significance.

(1) Osgood- Studies in Philology 1917-page 167.

(2) Cory- Criticism of Spenser-page 333. 
The Hymne in Honour of Love" begins with the cen-

sored minor key.

"Love, that long since has to thy mighty powre

Perforce subdude my poore captived hart,

And raging now therein with restless stowre,

- Doest tyrannize in everie weaker part;

Faine would I seeke to ease my bitter smart

By any service I might do to thee,

Or aught that else might to thee pleasing bee"!

He passes quickly through this less felicitous,

plaintive note to that mood of "sensuous innocence which

is always so winning but which is still of the earth earthy".

"Come then, o come, thou mightie God of Love,

Out of thy silver bowres and secret blisse,

Where thou doest sit in Venus lap above,

Bathing thy wings in her ambrosial kisse,

That sweeter farre than any nectar is;

Come softly, and my futle breast inspire

With gentle furie, kindled of thy fire"

Spenser describes the way in which

"This world's still moving mightie masse

Out of great Chaos ugly prison crept."

This creation was at the bidding of love, who made

"

his hardie flight

Through all that great wide wast, yet wanting light"

(1) Cory- Edmund Spenser-page 334.

(2) Hymne of Heavenly Love- lines 22-28.

(3) Ibid- Ines 57-58

(4). Ibid- Iines 68 to 70 
From the midst of this Chaos, Love ordered the discordant elements to arrange themselves in order, so that the world was created. (1)

For a moment the thought of Beauty allures him once more into his old wirful complaints, and conjures up the mischievous Cupid who rejoices in vain pranks with man as soon as he sees him in quest of Beauty.

"Which well perceiving, that imperious boy Doth therewith tip his sharp empoisned darts; Which, glancing thru the eyes with countenance coy Rest not till they have pierst the trembling harts, And kindled flame in all their inner parts, Which suckes the blood, and drynketh up the lyfe of carefull wretches with consuming griefe."

"Here we are at the heart of that unworthy mood that Spenser, remembering the supreme court of the muses and their special gift to him of high-seriousness, would fain have altogether erased, but was forced to send forth, accompanied by the last two soaring hymns. Yet just here, for the moment, doubt assailed the poet. Is love a truly benignant force or is not Love a pitiless wanton god who laughs at the grief his caprices cause? Spenser sets himself earnestly to understand this apperent injustice and soon sees that it is well. For, while ignoble love comes with every gust of whim, the highest Love cannot be invoked with a moment's fancy"

(1) Greenlaw, Edwin- Studies in Philology, 1920-XVII.

(2) Hymne of Heavenly Love- Lines 120-126.

(3) Cory- Edmund Spenser- page 330. 
"The fundamental weaknness of the mediaeval doctrine of love, despite its refining influence and its exaltation of woman, was that it proved unable to justify love ethically against the claims of the counter-ideal of asceticism. Taking

- its rise in a relationship which excluded the thought of marriage as the end, justification of love, which presumed in theory that the relation of the 'servant' to his lady must always be one of reverent and unrewarded service, this poetry found itself involved from the beginning in a dualism from which there was no escape" (1)

In the "Hymne in Honour of Beautie" Spenser is concerned chiefly with the platonic doctrine of ideas. Beauty of earth, he says, is but the shadow of the divine idea of beauty, and one should endeavor to comprehend this universal beauty through joy in contemplation of its earthly counterpart. After an invocation to Aphrodite whom he implores both to help him praise herself and to win his lady so that "It may so please, that she at length will streame

Some deaw of grace into my withered hart, After long sorrow and consuming smart," the poet philosophizes and hamonizes Fecine's notion that beauty is the "lively grace" of God's light with the brilliant theory of Plato in the "Timaeus", that beauty is a great unchangeable pattern from which the supreme Artificer modeled the world.

The true theme of Spenser's "Hymne of Heavenly Love"

(1) Grierson, H. J. C.- Introduction to Donne's Poetical Works - page 35. 
is the account of Lucifer's rebellion and his punishment In hell, of man's creation and fall, and of Christ's life on earth and sacrifice in order to redeem man.

The last "Hymne" emphasizes the idea of the mystical

- vision to be gained through contemplation of God and his works. In the "Hymne of Heavenly Beautie" the poet who has been at the foot of the stairway to eternity lifting his hands in exalted adoration ascends with eager reverence.

"Rapt with the rage of mine own ravisht thought, Through contemplation of those goodly sights, And glorious images in heaven wrought, Whose wondrous beauty, breathing sweet delights, Do kindle love in high conceipted sprights, I faine to tell the things that I behold, But feele my wits to faile, and tongue to fold".

In this last hymn, perfection, or contemplation proper, the complete development of the soul, is attained.

"Spenser's editors have been, I think, unnecessarily troubled by the poet's supposed repudiation of his earlier hymns in his dedication. If he had really been ashamed of the hymns to Love and Beauty, composed 'in the greener times' of his youth, why did he reprint them with their continuation in Heavenly Love and Heavenly Beauty? Surely the consistent thing to do would have been to print only the new work. But the explanation is not difficult if we take into account the continuity of the four poems, a continuity made plain not only by the development of the thought."

(1) Greenlaw, Edwin- Studies in Philology 1920-XVII, page 347. 
(1)

thinks that the publication of the erotic together with the religious odes is rather suspicious, that it is an admission of imperfect conversion, of incomplete repentance. That is not necessarily true, because, as

- Greenlaw has pointed out, spenser has preserved the continuity of thought and at the same time has presented to us the contrast between sensuous love and beauty and heavenly love and beauty. These reasons alone, if no other, justify Spenserts plan of publishing all four hymns at one time. He is a real'artist and works in "many ways his wonders to perform". As I said in the beginning of this discussion, one cannot hold that Spenser's retractation or confession is a Bunyan-like repentance. Far be it from such. I do think that Spenser was sincere in his retractation, not solely from the point of the religious enthusiast but from the viewpoint of the sincere artist as well. He sought to preserve that which was highest, noblest and best in English poetry.

His was the confession of a proudly sensitive and serious artist. If in his youth he had written verses of a light flippant nature, verses that were not fitting to one of his high rank, was it not quite natural that he should retract?

"In truth, whatever virtue there is in the subjectmatter of Spenser's poetry proceeds not from the ideas themselves so much as from the mind of the poet. At whatever point the reader penetrates Spenser's artistic motives-

(1) Legouis - Spenser- page 42. 
whether he has regard to the exquisite sweetness of his Iyric verse, as shown in "The Fowre Hymnes"; or to the graceful dignity of his personal compliments, as illustrated in his pastoral episodes; or to the moral grandeur of his sentiments in the second book of the "Frery Queen" -- there he will find the working of an almost incomparable poetical intelligence. Spenser composed his poems in the spirit of a great painter, a great musician. He 'writ no language' because he wrote about things that had no longer any existence except in his imagination. Yet so beautiful was his imagination that he has secured for the offspring of his fancy an enduring life, lllustrating the truth of his doctrine that

'Wise words taught in numbers for to run, Recorded by the Muses, live for ay'.

"A thing of beauty is a joy forever" - that is the secret of the enduring life of Spenser's poetry.

(1) Courthope- History of English Poetry,Vol.II-page 286. 

JOHN DONNE

There is something curiously and yet intermittently fascinating about John Donne. His reputation as a poet has passed through many vicissitudes in the course of the last three centuries. His fame has been fitful. After the obscuration of the eighteenth century, Coleridge and Lamb felt a charm for him which has been potent with some later critics. Browning was drawn to him by a congenial subtlety of intellect, and Lowell, an equally ardent lover of all that is quaint and witty, read and annotated him carefully. But Donne's poetry seems to be for the select few. "Not one of his lyrics appears in "The Golden Treasury, whether Palgrave disliked a style which is the antithesis of Tennyson's, or because he thought it unfit for the ordinary reader." $\left(\frac{1}{11}\right)$

Personally, I find Donne hard to read. His poetry contains the true spirit, but I rarely get to the end, even of the shortest lyrics, without being repelled by some discord in form or substance which is not at all pleasing to the average reader. Yet I am attracted as much as repelled. Donne himself excites my curiosity. What was the character and the mind that could utter itself in so unique a fashion? Nothing less could have been required than extraordinary talents at the service of a most peculiar ldiosyncrasy, and exposed to some trying combination of circumstance.

(1) Stephen, Leslie- National Review, Vol. XXXIV-page 525 
"With regard to his 'wit', its range and character, erudition and ingenuity, all generations of critics have been at one. It is as to the relation of this 'wit' to, and its effect on, his poetry that they have been at variance. To his contemporaries the 'wit' was identical with the poetry". (1).

What is today the value and interest of this wit which has arrested the attention of so many generations? How far does it seem to us compatible with poetry in the full and generally accepted sense of the word, with poetry which quickens the Imagination and touches the heart, which satisfies and delights.

Before entering upon the discussion of this difficult and debated question, one may first insist that in Donne's verse there is a great deal which, whether it be poetry in the full sense of the word or not, is arresting and of worth both historically and intrinsically. Whatever we may think of Donne's poetry, it is impossible not to recognize the extraordinary interest of his mind and character. The external facts in the life of this poet offer useful landmarks for the interpretation of his genius.

Izaak Walton in his short life of Donne has painted a figure of almost seraphic beauty. "From the 'good and virtuous parents' of the first line to the 'small quantity of Christian dust' of the last, every word is the touch of a cunning brush painting a picture". Walton's picture is

(1) Grierson, H. J. C.-Donne's Poetical Works-Vol. II-page $\$$.

(2) Lynd, Robt. - The Art of Letters- page 29.

(3) Symons, Arthur- Figures of Several Centuries, page 80. 
so beautiful because everything in it is sacrificed to beauty. Donne is the distinguished and saintly person, easily explicable.

In Edmund Gosse's "Life and Letters of Donne" we are able, if not indeed to see Donne as he really was, at all events to form our own opinion about every action of his life. In Gosse, Donne becomes more complex at every moment. He is a fascinating and puzzling creature whom each of us may try to understand after his fashion.

Since it would be impossible for us to understand Donne's poetry without a fair knowledge of his life, I shall give a brief summary of the poet's biography here.

John Donne was born about 1573, the son of a London merchant, whose wife was the daughter of John Heywood, the epigrammatist. In his eleventh year he was entered at Hart Hall, oxford, whence he was removed before he was fourteen to Cambridge, a proof of great precocity of intellect, even in an age when men's academical education began much earlier than at present. In neither university did he take a degree, perhaps because his family was of the Roman Catholic faith. From Cambridge he was removed to Lincoln's Inn, and by the death of his father became master of his fortune. This he seems to have rapidly dissipated, and after some years of loose living, he jolned Essex in the expedition to Cadiz in 1596, and again in the voyage to the Azores, during which he wrote his two poems entitled "The Storm" and "The Calm".

(1) Courthope, W. J.- History of English Poetry, Vol.III-pages $148-9$ 
From the latter we gather the causes which prompted him to his adventures:

"A rotten state, and hope of gain

Or to disuse me from the queasy pain

of being beloved and loving, or the thirst

of honour and fair death, out-pushed me first".

On his return to England he entered the household of Sir Thomas Egerton, the Chancellor, afterwards Lord Ellesmere, where he met Anne More- daughter of Sir George More, Lieutenant of the Tower, and niece of Lady Egerton whom he secretly married in 1601. The marriage gave great offence to the lady's father, who procured that Donne, with two of his friends, Samuel and Christopher Brooke, who had helped him, should be thrown into prison. After remaining there for a short time he was reconciled to Sir George, and being reunited to his wife, lived with her for a while at Peckham and Mitcham, and then entered the household of Sir Robert Drury. He accompanied Sir Robert on an embassy to Paris, where he wrote his "Anatomy of the World," in praise of his patron's daughter, Elizabeth Drury, who died in 1610 , in her fifteenth year. In 1615, at the express desire of James I, but long after hesitation on his part, he took orders, was appointed by the King to be his chaplain, and was made D.D. by the University of Cambridge. Two years later he lost his wife, to whom he was devotedly attached, and who seems to have been the first steadying influence in his 1ife. Iincoln's Inn appointed him preacher in 1617, and in 
the same year he accompanied Lord Hay on his embassy to Germany. Being appointed Dean of St. Paul's in 1621, he passed ten years of broken health and domestic solitude till his death, which occurred on March 31,1631 . His mind during the latter part of his life seems to have been occupied with the steady contemplation of his end, in conformity with the advice which he gives to the reader in the second anniversary poen of his "Anatomy of the World":-

"Think that they shroud thee up, and think from hence They reinvest thee in white innocence".

In his last illness he caused himself to be wrapped in his shroud and laid in his coffin, and in that guise to be painted; his effigy thus portrayed is preserved among the archives of St. Paul's cathedral.

From this sketch of Donne's life we pass to the study of his poetry. The character of his poetry reflects very exactly the changes in his life and opinion.

Donne's mind, if I may make my own attempt to understand him,was the mind of the dialecticlan, of the intellectual adventurer. He writes verse, first of all, because he has observed keenly, and because it pleases the pride of his intellect to satirize the pretensions of humanity. "Then it is the flesh which speaks in his verse, the curiosity of woman, which he has explored in the same spirit of adventure; then passion, making a slave of him for love's sake, and turning at last to the slave's hatred; finally, religion, taken up with the same intellectual 
interest". He took his own poems very seriously, he worked upon them with the whole force of his intellect; but to himself, even before he became divine, he was something more than a poet. Poetry was but one means of expressing the many-sided activity of his mind and temperament.

Donne was interested in everything. He was versed in medicine and the law as well as in theology. He subdued astronomy, physiology, and geography to the needs of poetry. He was an insatiate student, as Walton tells us: "In the most unsettled days of his youth his bed was not able to detain him beyond the hour of four in the morning; and it was no common business that drew him out of his chamber till past ten; all of which time he was employed in study; though he took great liberty after it."

Donne was wanton and Imaginative in his youth. From his nineteenth to his twenty-third year he surrendered both body and mind to randon experience. The body took its pleasure, the mind ironically criticised, and both processes for the time were entirely superficial. (4)

No doubt some of this feverish activity, this uncertainity of aim, was a matter of actual physical health. We do not know at what time the wasting disease, of which he died, first settled upon him; but he seems to have been always somewhat sickly of body, and with just that at times

(1) Symons, Arthur- Figures of Several Centuries-page 83.

(2) Lynd, Robt. - The Art of Letters-page 31.

(3) Walton, Izaak - Iife of Donne.

(4) Faussett- John Donne-page 37. 
depressing, at times exciting, malady which tells most upon the whole organization.

That preoccupation with death, which in early life led him to write his "Biathanatos", with its elaborate apology for suicide, and at the end of life to prepare so spectacularly for the act of dying, was but one symptom of a morbid state of body and brain and nerves, to which so many of his poems and letters bear witness.

The earlier period of Donne's life is one during which his most individual and pregnant poetry, the anonymous lyrics and elegies, was written. To this clàss belong his "Satires", his "Songs and Sonnets", his "elegies", and "The Progress of the soul". That poetry is, on the whole, poetry which has been lived. There can be little difficulty, I think, in distinguishing two well-marked groups of these love poems. The earlier consists of poems of extreme youth, poems which betray the boy cast loose upon the streams of the senses and the sentiments with little rudder or anchor of the conscience, and which are permeated with a cynicism perilously near the borders of insolence.

"I can love her, and her, and you, and you, I can love any, so she be not true". Donne's earliest lyrics were doubtless, in Walton's words, "facetiously composed and carelessly scattered" He was still the light-headed pagan to whom life is vicarious piracy, and woman the objective of an illicit and transient

(1) Walton- Iife of Donne-page 62. 
adventure. He exults in the prospect of desire, clamouring for absolute freedom and promiscuity, and scoffing at those "poor heretics in love".

The next period is of a chastened mood - tender, delicate, sincere. One connects it inevitably with the long romance of Donne's married life, beginning with the "strange and fatal interview", and ending only with those desperate weeks of mourning that proved so critical a turning-point in his spiritual history.

Donne's early satires are valuable as the first manifestations of his attitude towards life. The spiced or merely dainty flavor of so much Ellzabethan verse was obnoxious to his robust taste. "Like the attenuated sweetness of some lingering perfume, it offended his crude virility and he launched his defiant challenge:

"I sing not, siren-like to tempt, for I am harsh".

It is not in the satires that his wit is to us most obvious. It is in the lighter of his love verses that Donne's laughing wit is most obvious and most agile. "Whatever one may think of the choice of subject, and the flame of a young man's lust that burns undisguised in some of his 'Eligies', it is impossible to ignore the dazzling wit which neither flags nor falters from the first line to the last." Many of his verses are in keeping with one's impression of the young Donne as a man setting out bravely in his

(1) Faussett- John Donne- page 62.

(2) Faussett- John Donne- page 43.

(3) Grierson, H. J. C.- John Donne-Vol. II- page 11. 
cockle-shell on the oceans of knowledge and experience. He travels, yet he knows not why he travels. He loves, yet he knows not why he loves. He must escape from that "hydroptic, immoderate" thirst of experience by yielding to it. In these lines we get a glimpse of the Donne of early years:

"Whether a rotten state, and hope of gain, or to disuse me from the queasy pain of being belov'd, and loving, or the thirst of honour, or fair death, out pusht me first." One of the most interesting of all the sensual intrigues of Donne is that of which we have the story in "Jealousy" and "His Parting from Her". It is a story of furtive and forbidden love. Its theme is carried on under a

II Husband's towering eyes,

That flamed with oily sweat of jealousy".

A characteristic touch of grimness is added to the story by making the husband a deformed man. Donne, however, merely laughs at his deformity, as he bids the lady laugh at the jealousy that reduces her to tears:

"O give him many thanks, he is courteous, That in suspecting kindly warneth us.

We must not, as we used, flout openly, In scoffing riddles, his deformity; Nor at his board together being set With words nor touch scarce looks adulterate". In"The Blossom" he is still in an earthly mood, and declares that, if his mistress remains obdurate, he will return to London where he will find a mistress: 
"As glad to have my body as my mind."

"The Primrose" is another appeal for a less intellectual love:

\section{"Should she}

Be more than woman, she would get above

All thought of sex, and think to move My heart to study her, and not to love."

It seems to me that it is useless to look in Donne for a single consistent attitude to love. "He was by destiny the complete experimentalist in love in Fnglish literature. He passed through phase after phase of the love of the soul on- $1 \mathrm{y}$, and ended as the poet of the perfect marriage."

I cannot dwell longer upon the early, sensuous poetry of Donne. Enough has been quoted to show the type of poetry which he wrote in his early life.

From the early period Donne passes from "infidelity to fidelity, from wandering amorousness to deep and enduring passion. The image that is finally stamped on his greatest work is not that of a roving adulterer, but of a monotheist of love". (2)

A graver and more philosophic period follows, in which were produced most of the "Verse Epistles", "The Anatomy of the World," and his "Epicedes and Obsequies". In this period of his life when his opinions were becoming more settled and religious, he writes of his individual soul:

"Our soul, whose country's heaven, and God her father,

(1)

Lyndm, Robert- Art of Letters-page 38.

(2) Ibid-page 41. 
Into this world, corruption's sink, is sent;

Yet so much in her travel she doth gather,

That she returns home wiser than she went."

In "The Anatomy of the World" Donne seems to have

intended to embody his serious thoughts about the meaning and duties of human life. "The true character of The Anatomy of the World' is indicated in the respective titles of the two 'Anniversaries'. That of the first runs: 'Wherein by occasion of the untimely death of Mistress Elizabeth Drury, the frailty and decay of the whole world is represented.' The subject of the sec ond is defined thus: 'Wherein, by occasion of the religious death of Mistress Elizabeth Drury, the incommodities of the soul in this life, and her exaltation in the next, are contemplated'. In other words, the early death and religious character of Elizabeth Drury are merely the text justifying an elaborate exposition of Donne's philosophy of life."

On the whole, it seems to me probable that the publication of "the Anatomy of the World" was part of a deliberate literary design on Donne's part. His views of live were changing with his years: he was anxious for either secular or sacred employment; he regretted the evidences of a dissipated past which existed in his youthful poems. This was the transitory stage from the grave and philosophical Iiving and dying, to the saintly period of the poet's life. Donne searches, nothing satisfies him; he tries every-

(1) Courthope- History of English Poetry-VoI.III- pages 157-8. 
thing in vain. He finds satisfaction at last in the church as a haven of rest.

The crisis came when the death of his wife changed the world for him and be became, in the words of Walton, "crucifled to the world, and all those vanities, those imaginary pleasures, that are dally acted on that restless stage; and they were as perfectly crucified to him".

From that time on to the end of his life he had found what he had all the while been seeking; rest for the restlessness of his mind, in a meditation upon the divine nature; occupation, in being ambassador to God; himself, as it seemed to him, at his fullest and noblest. It was himself, really, that he had been seeking all the time.

In the religious poetry of Donne we come more closely to the subject, "Formal Retractation" or" Literary Repentance" The last period of Donne's poetical genius contains the "Divine Poems", comprising meditations on the various mysteries of Christian faith, a version of Tremellius' "Lamentations of Jeremiah", written after the death of muchloved wife, and other religious topics.

In the poems of divine love, there is the same quality of mental emotion as in the poems of humah love. But though his view of life and his object in art were thus completely altered, his poetical method remained consistently the same. As his admirer, Chudleigh, remarks:

"He kept his loves, but not his objects: Wit He did not banish, but transplanted it; 
Taught it his place and use, and brought it home

To piety which it doth best become;

He showed us how for sins we ought to sigh,

And. how to sing Christ's epithalamy."

The seven sonnets entitled "La Corona" have been generally attributed to this period, but it is probable that they were composed earlier, and their treatment of the subject of Christ's life and death is more intellectual and theological than spiritual and poetical.

Certainly it is only in the conclusion of "La Corona" that he completely transformed doctrine into impassioned poetry, and scriptural metaphors become symbolical rather than merely 1llustrative:

"O strong Ram, which hast batter'd heaven for me! Mild Lamb which with Thy Blood has marked the path! Bright Torch, which shinest, that of the way I may see! 0 with Thy own Blood quench Thy own just wrath; And if Thy Holy Spirit my muse did raise, Deign at my hands this crown of prayer and praises". It is when the tone becomes personal, as in the "Holy Sonnets", when he is alone with his own soul in the prospect of death and the Judgment, that Donne's religious poetry acquires something of the unique character as his love songs and elegies by a "similar combination of qualities, intensity of feeling, subtle turns of thought, and occasional

(1) Courthope- History of English Poetry-Vol. III-page 160.

(2) Grierson- John Donne- Vol. II, page 52. 
Milton splendour of phrase".

"Batter my heart, three-person'd God, for you As yet but knook; breathe, shine and seek to mend; That I may rise, and stand, oerthrow me, and bend Your force, to break, blow, burn and make me new". Grierson says of Donne's conversion: "When Donne
y crossed the Rubicon, convinced that from the King Grierson says of Donne's conversion: "When Donne
y crossed the Rubicon, convinced that from the King no promotion was to be hoped for in any other line of life, it was rather with the deliberate resolution that he would make his life a model of devotion and ascetic self-denial than as one drawn by an irrestible attraction or impelled by a controlling sense of duty to such a life. Donne was no st. Augustine whose transition from libertinism to saintliness was from within."

I do not agree with Mr. Grierson on this point. I think Donne entered the ministry, not for worldly gain and honor, but through a sincere love of God and a fervent zeal to do His work.

Many readers of Donne's poetry have felt strongly the incongruity of his position as a religious teacher. They are willing enough to admit the sincerity of the agonized penitence of the "Holy somnets", but they cannot fit the passionate, cynical, sensuous figure of the poet into the ecclesiastical gaments of the Dean of St. Paul's. They think, as does Mr. Grierson, that Donne must have felt himself to be playing a part.

(1) Grierson- John Donne- Vol. II- page 52,

(2) Ibid-page 51 . 
It is worth while to examine Donne's mature teaching in order to see whether there is any foundation for the sense of incongruity. Did Donne preach doctrines which held for him no vital meaning? Was there a taint of insincerity about his work?

He has left us ample material for such an investigation in the "Sermons", the "Devotions", and the "Letters". "Those who, like Dr. Jessopp, have become familiar with the huge tomes of his writings have not hesitated to express their profound belief in his sincerity. They have marvelled that the English Church has taken so few pains to honour a man whom she might have regarded as one of her brightest ormaments of learning and devotion. -- An examination of the "Sermons" shows that there is nothing really heterodox in Donne's mature opinions. In his youth he had propounded certain heretical views on such doctrines as the transmigration of souls ('Progresse of the Soule') and the nature of woman ('Juvenilia'). In the 'Sermons' he retracts these opinions and there is no evidence to prove that he had ever held them seriously or had regarded such subjects as anything but stalking-horses for the display of his youthful wit." Critics complain that Donne lacks reverence, that he is sensual, arrogant, and too fond of intellectual display. This is true in part, especially of his early work, both in prose and poetry. Yet there is in him an element, hard to analyze, but unmistakable, giving to all his work a peculiar

(1) Simpson, E. M. - Prose Works of Donne-pages 66-7. 
intensity, and bringing unity out of the diversity of his many and apparently contradictory qualities. "The poems are full of the mystical consciousness of the one behind the many. It is this which dominates his idea of the relations between God and the universe, man and woman, body and soul, God is not apart from the universe. He is in every part of it, and in Him we live and move and have our being."

If Donne had given us a record of the experiences which led up to and followed his conversion, we should not be left with many gaps, and obscurities when we try to piece together some of the fragments of personal experience which are scattered throughout the mass of the poems, sermons, and letters: The world around noted the change in him and friends like Walton observed his growth in holiness and detachment from earthly things. Such a transformation does not take place without agonies of heart and soul. To Donne, with his strong passions and vivid memories of his earthlier sins, it must have caused the keenest suffering.

I think the following extracts from Donne's poems clearly show the sincerity of his repentance.

A careful study of Donne's works shows that the particular sins for which he felt the deepest repentance were those sins of the flesh committed in his youth. Again and again he laments the ruin wrought in his soul by wantonness and lust:

(1) Simpson, E. M.- Prose Works-page 98. 
"In mine Idolatry what showres of raine

Mine eyes did waste? What griefs my heart did rent?

That sufferance was my sinne, now I repent;

'Cause I did suffer I must suffer paine".

In the following passage Donne repudiates sin with

the same violent subtlety with which he embraced it:

"I am a little world made cunningly

of Elements, and an Angelike spright,

But black sinne hath betraid to endlesse night

My worlds both parts, and (oh) both parts must die.

---But oh it must be burnt! alas the fire

of lust and envie have burnt it heretofore,

And made it fouler; Let their flames retire,

And burne.me, 0 Lord, with a fiery zeale

of thee and thy house, which doth in eating heale".

Donne felt that the guilt of these past sins was aggravated by the fact that he had alluded to them and even glorified them in some of his early poems. Truly, these poems were never published during his life-time, and according to Walton and Ben Johnson, he repented deeply of them and sought to destroy all available coples. Walton in his "Life" says: "It is a truth, that in his penitential years, viewing some of those pieces that had been loosely (God knows too loosely) scattered in his youth, he wish't they had been abortive, or, so short liv'd that his own eyes had witnessed their funeral". (3) with William Drummond", says of Donne: "and now, since he

(1) Holy Sonnets- Number III-lines 5-8-Grierson- p.323

(2) Ibid- Iines $1-4,10-14$.

(3) Walton- Iife of Donne-page 53. 
was made Doctor, repenteth highlie, and seeketh to destroy all his poems."

But Donne's reputation as a poet was considerable, and his verses had enjoyed a wide circulation in manuscript, which made this attmpt unsuccessful. Doubtless it was the thought of these poems which gave sting to the idea, expressed in several of his sermons, that in hell the authors of licentious books or pictures may suffer additional tortures for the sins which others have committed at their instigation.

Donne was, however, sufficiently convinced of the truth of the Christian doctrine of the Atonement to believe that his repentance for these sins had been accepted in virtue of his faith in the blood of Christ. In the Holy Sonnets" he communes with his own soul:

"Yet grace, if thou repent, thou canst not lacke; But who shall give thee that grace to beginne? Oh make thyself with holy mourning blacke, And red with blushing, as thou art with sinne; Or wash thee in Christ's blood, which hath this might That being red, it dyes red soules to white."

But though he belleved that his past sins had been forgiven he often expressed his fear of a relapse. This is to be explained by the doctrine that a remembrance of former sins, except for the purpose of confession and repentance, is an actual renewal of the offense. This belief is expressed in one of his "Sermons": (3) "A conscience is not clean, by

(1) Sermons - number 47- page 445 .

(2) Holy Sonnets- number IV- lines 9-14.

(3) Sermons - number 49-page 463. 
having recollected all her sins in the Memory, for they 'may fester there, and Gangreen even to Desperation.---How many men sin over the sins of their youth again, in their age, by a sinful Delight in remembering those sins, and a sinful Desire, that their Bodies were not past them?"

His "Hymn to Christ" is a devout echo of the change that has come about in the poets soul.

"I sacrifice this Island unto Thee And all whom I love there, and who love me; When I have put our seas 'twixt them and me, Put thou Thy seas betwixt my sins and Thee; As the tree's sap doth seek the root below In winter, in my winter now I go Where none but the Eternal Root of true love I may know."

"But he that makes our crosses Anchors thus, Is Christ, who there is crucified for us. Yet with this I may my first Serpents hold;God gives new blessings, and yet leaves the oldThe serpent, may, as wise, my pattern be; My poise, as he feeds on dust, that's me. And, as he rounds the earth to murder, sure He is my death; but on the Cross, my cure Crucify nature then; and then implore All grace from him, crucified there before." Death itself, Donne argued, was a like crufixion, and that Christ should have endured and survived it was 
indeed full of consolation and hope, if only he himself could have silenced the lurking incredultty of his mind and the gross awareness of his senses.

And it is clear that, however spotless Donne's outer

- Iife became, he had to wrestle through many years with thoughts and desires which he regarded as sinful. It is the conflict of the lower with the higher self, of the spirit with the flesh, that gives a strange intensity to all Donne's devotional work, whether in poetry or prose.

This same inward strife is also expressed in the "Devotions upon Fmergent Occasions", not written until 1623, six years later than the "Holy Sonnets".

"The whole tone of Donne's moral teaching is positive rather than negative. He expressed this in a quaintly worded passage on one of the penitential psalms: 'The Negative man, that trusts in nothing in the world, may be but a Philosopher, but an Atheist, but a stupid and dead carcasse. The Affirmative man, that does acknowledge all blessings, spirituall and temporall, to come from God, that prepares himself by holiness to be fit to receive them from God, that comes for them by humble prayer to God, that returnes for them humble thanks to God, this man hath the first marke of this person upon him', 'He trusts in God.' "

The words of Browning in "La Saisiaz" are true of Donne:

"He then with the brand flamboyant, broad odr night's forlorn abyss

Crowned by prose and verse; and wielding, with wit's

(1) Simpson, E. H.- Prose Works of Donne-page 129. 
bauble, leaming's rod....-

-Well? Why, he at least believed in Soul, was very sure of God."

"It is true that there is enough Don-Juanism in the poems to have led Sir Thomas Browne to think of Donne's verse rather as a confession of his sins than as a golden book of love. Browne's quaint poem, 'To the deceased Author, before the Promiscuous printing of his Poems, the Looser Sort, with the Religious', is so little known that it may be quoted in full as the expression of one point of view in regard to Donne's work:

'When thy loose raptures, Donne, shall meet with those That do confine

Tuning unto the duller line, And sing not but in sanctified prose, How will they, with sharper eyes, The foreskin of thy fancy circumcise, And fear thy wantonness should now begin Example, that hath ceased to be sin! And that fear fans their heat; whilst knowing eyes Will not admire

At this strange fire

That here is mingled with thy sacrifice, But dare read even thy wanton story As thy confession, not thy glory; And will so envy both to future times, That they would buy thy goodness with thy crimes'." (I)

(1) Lynd, Robt. - Art of Letters - page 41 
In estimating Donne's position as a poet, "The Camb(1)

- ridge History of English Literature" says: "For evil and for good, Donne is the most shaping and determining influence that meets us in passing from the sixteenth to the seventeenth century. In certain aspects of mind and training the most medieval, in temper the most modern, of his contemporaries, he is, with the radically more pedantic and neo-classical Jonson, at once the chief inspirer of his younger contemporaries and successors, and the most potent herald and pioneer of the school of poetic argument and eloquence."

I have not tried to picture Donne as faultless. His life, his poetry, his prose writings and his sermons are full of faults, flaws of construction in his poetry, improprieties in his life, obscurity of thought and sensuality. And yet, with every fault, there is an over-balancing virtue which grips and keeps our interest.

"Splendid and obscure he was", Gosse says, "In the extreme versatility and passion, the profundity, the saintIiness, the mystery of his inscrutable character. No one, In the history of English literature, as it seems to me, is so difficult to realize, so impossible to measure, in the vast curves of his extraordinary and contradictory features--- He was not the crystal-hearted saint that Walton adored and exalted. He was not the crafty and redoubtable courtier whom the recusants suspected. He was not the prophet

(1) Cambridge History of Fnglish Literature-Vol.IV- page 227.

(2) Gosse- Life and Letters of Donne-Vol.II- page 290. 
of the fntricacies of fleshly feeling whom the young poets

- looked up to and worshipped. He was none of these, or all of these, or more. What was he? It is impossible to say, for, with all his superficial expansion, his secret died with him. We are tempted to declare that of all great men he is the one of whom least is essentially known. Is not this, perhaps, the secret of his perennial fascination?" 
SEVENTEENTH CENTURY POETRY. 
In this study I shall attempt to treat the poetry of those writers of the seventeenth century who most clearIy show the influence of Spenser and Donne, and in whose poetry one finds specific instances of personal retractation or literary repentance. As we know, from a careful study of Elizabethan poetry, the two waves of influence that mark the trend of seventeenth century poetry are those of the "School of Spenser" and the "School of Donne."

As we pass into the seventeenth century we find that (1) poetry has grown self-conscious. The earlier ardours of the time of Elizabeth were now on the wane. Poets readily became more moral or religious, sometimes more didactic. A general more sombre or more melancholy hue was diffused over letters. Poetry was already a little under the shadow of the approaching great civil conflict, of the strengthened and menacing Puritanism. Some of the poets reverted to the Elizabethan manner, but the age had lost the first freshness of invention.

At the very end of Elizabeth's reign and under James I, several poets flourished who are variously interesting, some who had received an impulse from their predecessors and others who adventured in new paths. I shall confine my study to those poets whose works present examples of personal re tractation or literary repentance. They are the following: Robert Herrick, Thomas Carew, George Wither, and Henry Vaughan.

(1) Legouis, Emile- History of English Literature, Vol.I-page 208. 


\section{$-87-$}

\section{ROBERT HERRICK}

Midway between the Cavaliers and the Anglicans, Robert Herrick, a very gifted and exquisite poet, has place. The anacreonticism of the poetry of his youth makes him one of the Cavaliers, and since, at the age of thirty-eight, he accepted a Devonshire living and did his best to convert his Muse, he is also to be numbered among the Anglicans.

A brief summary of Herrick's life will help us to understand his poetry. (2) in 1591. He studied at Cambridge, and having entered into holy orders, was presented by Charles I in 1629, to the vicarage of Dean Pryor in Devonshire. After about twenty years'residence in this rural parish, Herrick was ejected from his living by the storms of the civil war, which, as Jeremy Taylor says, "dashed the vessel of the church and state all in pieces". Whatever regret the people may have felt on being turned adrift on the world, he could have experienced little on parting with his parishioners, for he described them in much the same way as Crabbe portrayed the natives of Suffolk, among whom he was cast in early life, as a "wild amphibious race" rude "almost as savages" and "churlish as the seas". Herrick gives us a glimpse of his own character:

"Born I was to meet with age, And to walk life's pilgrimage:

(1) Legouis- History of English Literature, Vol.I- page 349. 
- Much,I know, of time is spent;

Tell I can't what's resident.

Hoẃsoevér, cares adieu!

I'Il have naught to say to you;

But I'Il spend my coming hours

Drinking wine and crowned with flowers."

About the time that he lost his vicarage, Herrick appears to have published his works. His "Noble Numbers", or "Pious Pieces", are dated 1647; his "Hesperides", or the "Works both Humane and Divine of Robert Herrick, Esquire", in 1648. The clerical prefix to his name seems now to have been abandoned by the poet, and there are certainly many pieces in his second volume which would not become one ministering at the altar, or belonging to the sacred profession.

Resentment, at the wrong done him when he was ejected from his living, seems to have been out-weighed in his mind by his joy at returning to London. During the Commonwealth he appears to have been supported in London by the generosity of Endymion Porter, one of the chief literary patrons of the time, but in 1662 he was replaced in his living, and continued it till his death in october 1674, when he was buried in the churchyard of Dean Prior.

Herrick associated with the jovial spirits of the age. He "quaffed the mighty bowl" with Ben Jonson, but could not, he tells us, "thrive in frenzy", like rare Ben, who seems to have excelled all his fellow competitors in sallies of wild wit and high imaginations. Just when or how Herrick 
became "sealed of the tribe of Ben" is not recorded, but - of his intimacy with the master there can be no doubt.

Herlick's poems fall into three groups: his epigrams which are coarse and heavy-handed in both feeling and expression; religious poems which belong to the rather small company of "divine" lyrics in English that are of fine poetic quality; and perhaps a thousand secular poems, chiefly anatory or descriptive, which constitute the body of his work. The beautiful religious lyrics form but a fraction of his poetical work and not the part for which he is most distinguished. The most memorable of the "Hesperides" songs are those which sing of hock-carts, country wakes, and Devon maidens going a-maying. Herrick has himself summed up, very correctly, the themes of his sylvan muse when he says:

"I sing of brooks, of blossoms, birds and bowers, Of April, May, of June and July flowers, I sing of May-poles, hock-carts, wassails, wakes, of bridegrooms, brides and of their bridal-cakes."

It is impossible to dwell longer upon the secular poetry of Herrick. I am concerned more with the religious poems, or "Holy Numbers", than with the epigrams, pastorals and love lyrics of this writer. To sum up the secular poetry, I wish to say that many of the poems are really worth while. His love poems are very beautiful; the best of them have an ardour and tender sweetness which give them a place in the forefront of modern lyrical poetry. 
- Let us turn our attention to Herrick's religious - poetry and try to determine the nature of the repentance of this truly complex and mysterious writer.

First of all, what were the religious convictions of Herrick? We have few hints of his life as a clergyman. No one seems to know why he took orders. He says himself he was not ordained for the loaves and fishes. He loved London, and addressed his new country as "lothed Devonshire" One cannot look in his face, or think of the life of wit and wine in which he had delighted in the metropolis, and believe that nature had designed him for a country incumbency. But he started with at least good resolutions. There is an "Ode Upon Parting" in which he takes leave of the lusts of the flesh and fame, and a "Farewell Unto Poetry" -- that is, all poetry save the "Noble Numbers" of sacred song. Herrick's religious convictions were assuredly not deeper than those of the average layman.

Various writers have taken a different view of the subject; but it is inconceivable that a clergyman with a fitting sense of his function could have written certain of the poems which Herrick afterward gave to the world - those astonishing epigrams upon his rustic enemies, and those habitual bridal compliments which, among his personal friends, must have added a terror to matrimony. Had he written only in that vein the posterity which he so often invoked with pathetic confidence would hot have greatly troubled itself about him. 
Though his rhymes were sometimes wild, he says his life was chaste, and he repented of his errors, in "His Prayer for Absolution":

"For those my unbaptized rhymes, Writ in my wild unhallow'd times; For every sentence, clause, and word That's not inlaid with thee, my Lord. Forgive me, God, and blot each line Out of my book, that is not thine. But if, 'mongst all, thou finds here one Worthy thy benediction, That one of all the rest shall be The glory of my work and me."

The poet might have evinced the depth of his contrition by blotting out the unbaptized rhymes himself, or by not reprinting them; but the vanity of the author seems to have triumphed over the penitence of the Christian. The religious poems may have been written later than the least decorous verses, though we cannot be sure of it.

Herrick's piety, however sincere in intention, is at times disconcerting. It is his frankness, his candor that perplexes.

Here and there a beautiful and sensitive poem interrupts the sequence of theology. Herrick was a man of numberless caprices, though still himself through all. There is a penitence that comes with surfeit and languishes with returning appetite, and religion and superstition can be inextric- 
$\because$ ably intertangled in one quite ordinary mind. If it were possible to follow it, there could be no more satisfactory morality than the blandishing exhortations of "Hesperides", "To enjoy the time", "To welcome what comes", "To live merrily, and to trust to Good Verses".

Herrick is genial, naif, playful at times; there is a spontaneousness about him, a sincerity that disarms criticism. (1) Take this characteristic little poem, "To his Conscience"! :

"Can I not sin, but thou wilt be My private prothonotary? Can I not woo thee to pass by A short and sweet iniquity?

I'Il cast a mist, a cloud upon My delicate transgression, So utter dark, as that no eye Shall see the hugged impiety: Gifts blind the wise, and bribes do please, And wind all other witnesses; And will not thou with gold be tied To lay thy pen and ink aside?

That in the mirk and tongueless night, Wanton I may, and thou not write?

It will not be. And therefore, now, For times to come, I'Il make this vow: From aberrations to live free, So I'll not fear the Judge, or thee."

(1) Schelling- Seventeenth Century Iyrics-page 36. 
- There is not any lack of clear, vision here; yet who believes in the seriousness of this pretty repentance? This "vow" is of the same nature as his vows to Apollo, Bacchus, (1) or Venus:

"Make her this day smile on me And I'll roses give to thee".

- In "His Confession", Herrick says :

"Look how our foul days do exceed our fair: And as our bad more than our good works are, Ev'n so those lines, penn'd by my wanton wit, Treble the number fo these good I've writ. Things precious are least numerous: men are prone To do ten bad for one good action."

It is quite difficult to understand Herrick's religion and the nature of his "repentance". I think the following lines give, manifestly, the real religion of the poet:

\footnotetext{
"When I a verse shall make,

Know I have pray'd thee, For old religion's sake, Saint Ben to aid me."
}

This is a pretty paganism masquerading in Christian forms and with no sense of the incongruity in such a mixture. We are today, perhaps, unduly impressed by this contamination (in the technical meaning) of blending Apollo and Jesus, Saint Ben and St. Paul, because the contemporary religious

(1) Schelling - Seventeenth Century Lyrics - page 36. 
poets were turning for their inspiration to a pure platonic Christianity, and because Herrick was a priest of the church in good and regular standing. Again we are quite ignorant of the reasons which led him to take orders and of the time of his consecration. We suddenly hear of him as chaplain in Buckingham's army on the 111 fated expedition to the Isle of Rhe in 1627. Two years after this he was presented to the vicarage of Dean Prior in Devonshire, and we have henceforth to think of Herrick as a country parson.

There is in his verse not a trace of that feeling of high consecration in office which we naturally expect from one of his position. One suspects that he never got close to the heart of the people about him or understood their more intimate joys and sorrows. His imagination is "for sports, for pagaentries, for plays," and his mind rerely rises higher than the prettiness of a flower.

\section{(1)}

Legouis says that Herrick was induced to take orders only for the sake of a livelihood. He says further: "When he bade farewell to London and his Muse and departed to his living of Dean Prior, in Devonshire, he resolved to be a good parson. But he had no enthusiasm for his new duties. The change was too great for him. But little by little he acquired a taste for the rich country side in which he found himself and for the uses of rustic life. He became attached also to his church and his little vicarage; he trusted in the good people's God, to whose infinite indulgence he could leave the frolics of his youth and certain

(1) Legouis - History of English Literature-Vol.I- page 349. 
- lapses of his maturity, whose anger would not be roused because the very secular 'Hesperides' were printed side by side with the 'Holy Numbers'. 'Jocund his Nuse was, but his life was chaste', he said of himself. This was self-flattery. His portrait at the beginning of 'Hesperdes' shows a torso like that of a merry Priapus, a sensuous, mocking youth beneath an aquiline nose, a head bristling with crisp, luxuriant hair, a chest left bare. This is a real pagan from a garden where Cupids dance in a ring, while Pegasus, standing on a hillock, is poised for flight."

Herrick followed the example of Donne in dedicating his powers to religion, when he entered the church; but, unlike Donne, he could not break with the past or change the temper of his mind. His materialistic nature and sensuors fancy are as manifest in many of his religious verses as in his secular, and some of his poetic addresses to God are incongruously like those to his "peculiar Lar". "Donne's 'Litany' may well have inspired Herrick to write his 'Litany to the Holy Spirit'; but the character of the two priests, as revealed in their respective poems, is entirely different".

of Herrick's religion, I shall not say it was insincere or hypocritical because the gods of Anacreon were as real to him as the God of the Gospels; but we may think he came nearest to his real sense of worship, not in the "Litany" or "The White Island," beautiful as are those chants, but rather in his "Thanksgiving to God for His House":

"Lord, thou hast given me a cell

(1) Moorman, F. W. - Poetry of Herrick-page 5. 
Wherein to dwell;

And little house, whose humble roof

Is weather-proof;

Under the spars of which I lie

Both soft and dry;

Where thou my chamber for to ward

Hast set a guard

of harmless thoughts, to watch and keep

Me, while I sleep."

"All these and better thou dost send

Me, to this end,

That I should render, for my part,

A thankful heart;

Which, fir'd with incense, I resign,

As wholly thine;

But the acceptance, that must be,

My Christ, by thee."

of the "Holy Numbers", Gosse (1) says: "Here our pagan

priest is seen despoiled of his vine wreath and his thyrsus, doing penance in a white sheet and with a candle in his

hand. That rubicund visage, with its sly eye and prodigious jowl, looks ludicrously out of place in the penitential surplice; but he is evidently sincere, though not very deep in his repentance, and sings hymns of faultless orthodoxy with a loud and lusty voice to the old pagan airs."

(1) Gosse, Edmund- "Seventeenth Century Studies"- page 72. 
"Herrick reminds us at one time of the Greek epigrammatists; at another of Catullus, or Horace, or Martial; now of Ronsard, and then of Ben Jonson. But he is always original. He polished his verses carefully...-Though he professed a distaste for his Devonshire vicarage, no poet has described with equal gusto the delights of old English country life -- the wakes and wassails, the May-day games and harvest-homes. In his 'Hesperides' he is the most

- frankly pagan of English poets, but his 'Noble Numbers' testify to the sincerity of his Christian piety."

To sum up the poetry of Herrick, and to come to some conclusion as to the nature of his repentance, I wish to say that one should not take too seriously the extraordinary materialism of thought found in many of the poems. Herrick was, far beyond all the poets of his age, an artist, and the air of consciousness that mingles with his simplicity shows that he handled sentiments and words in metre mainly with a view to the beauty of expression.

"Herrick was in spirit an Elizabethan, and had strayed by chance into an artificial and prosaic age -- a sylvan singing creature alighting on an alien planet. He was too natural, too purely poetical; he had not the learned polish, the political allusion, the tone of the city, the didactic turn, which were then and onward demanded from poetry." "(2)

Among all the singers of a day when England was a

(1) Dictionary National Biography- Vol. XXVI- page 255.

(2) Century Classics- Pdems of Herrick-page 35. 
hest of singing-birds, Herrick ranks as one of the greatest. -We do not admit the sincerity of Herrick's repentance, but we must agree that he is a great artist and wrote some beautiful poetry. His poetry is summarized in a little poem, not included in "Hesperides", and discovered in manuscript by Dr. Delattre -- "Upon a Cherrystone sent to the tip of the Lady Jemmonia Walgraves Eare" --

"Lady I entreate yow weare

This little pendant on your eare,

Tis not Jewell of great prize

Or in respect of Merchandize,

But deepe mistery, not the stone

Gives it estimation.

Take it then and in a viewe

See the 'Epitone' of yow"--

\section{THOMAS CAREW}

Among the Royalist lyrists of the seventeenth century Thomas Carew takes a foremost place. Born at the time when the trend of Finglish poetry was at its peak he lived to hand down to his followers a tradition that influenced ages to come. "In his hands English verse took a smooth and flexible character that had neither the splendours nor the discords of the great Elizabethan school, but formed an admirable medium for gentle thought and florid reverie".

(1) Ward, T. H. - The English Poets-Vol. II- page 113. 
Thomas Carew was born about 1589. He received his education at Corpus Christi College, oxford, where his genius and abilities early attracted notice. He was introduced to court, probably by his brother, and appointed Gentleman of the Privy Chamber, and Sewer in Ordinary to Charles I; which posts he retained until his death in 1639 .

Little is known of Carew's early life except that it was restless and dissipated. His life was that of a courtier-- witty, affable and accomplished-- without reflection; and in a strain of loose revelry which, according to clarendon, the poet deeply repented in his latter days. What caused the change in Carew's way of thinking, we do not know. His remorse for the licentiousness of some of his poetry is confirmed partly by contemporary poetical evidence. In a poem ascribed to George Wither and published after his death, entitled "The Great Assizes holden in Parnassus by Apol.10 and his Assessors," Carew is arraigned by the public accuser for the immorality of his verse:-"He said that he, by his luxurious pen, Deserved had better the Trophonian den Than many now which stood to be arrigned, For he the Thespian fountain had distained With foul conceits, and made their waters bright Impure, like those of the Hermaphrodite. He said that he in verse more loose had been Than old Chaerephanes or Aretine,

(1) Clarendon, Lord- Life of Carew- page 9. 
In obscene portraitures, and that this fellow

In Helican had reared the first Bordello."

This is much exaggerated, but Carew makes his defence by saying:

"In wisdom's nonage and unriper years

Some lines slipped from my pen, which, since, with tears,

I laboured to expunge."

In the poem "Pleasure", Carew shows his distrust of

all that is earthly:

"Bewitching siren! golden rottenness!

Thou hast with cunning artifice displayed

Th'enamelled outside, and the honeyed verge

of the fair cup, where deadly poison lurks.

Within, a thousand sorrows dance the round;

And, like a shell, pain circles thee without.

Empires, that know no limits but the poles,

Have in thy wanton lap melted away.

To thy voluptuous den fly, witch, from hence;

There drowned forever in brutish sense."

Carew was the author of miscellaneous poems, a few of which were of a religious nature; these latter have great beauty and simplicity. Clarendon the historian says that "Carew died with the greatest remorse for the licence of loose revelry, and with the greatest manifestation of Christianity that his best friends could desire."

(1) Courthope, W. J.- History of English Poetry-Vol.III-page 63.

(2) Clarendon, Lord - Life of Carew- page 9. 
The poetry of Carew is often indelicate but rich in expression. Thirty or forty years later he would have fallen into the frigid style of the court-poets after the Restoration; but at the time he wrote, the passionate and imaginative vein of the Elizabethan period was not wholly exhausted. The "genial and warm tints" of the elder muse still colored the poetry of the time and were reflected back in some measure by Carew.

Passing from the court wits, we come to the poetry of Wither and Vaughan who present a combination of the socalled "poetical wit" with "theological wit."

GEORGE WITHER

George Wither was of a sharp satiric genius. Given to meditation, nursed in an indulgent atmosphere, he was one of those impracticable characters that can never make allowance for their surroundings.

Born of a good family at Bentworth in 1588, he was sent, at the age of 16 , to oxford. Called home by his father to hold the plough, he was afraid of being put to some mechanical trade and he contrived to escape to London where he wished to try his fortune at court. The manners of the court were not to his taste, and he indulged his satiric temper at the expense of his fortunes. To show his independence he wrote "Abuses Whipt and Stript", a satire directed against 
vices common to humanity. This satire offended many classes and the author was imprisoned. While in prison he wrote his "Shepherd's Hunting." Upon the restoration, the estates he had acquired were taken from him, and he was cast into prison, where, after being treated with great severity for three years, he died in 1667.

Wither was a Puritan by conviction. In "Britain's Remembrancer" it is evident that the Puritanic element in his nature was intense. "Personal suffering, frequent quarrels with authority, what seemed the manifest judgments of God on the country in the plague and other public calamities, exalted in him the temper of religious mysticism and allenated him more and more from the manners of the court.

Toward the end of his life, his literary productions consisted either of hymns and religious exercises or of violent political diatribes, In the poem "Hallelujah", stern Puritan faith is the subject. The poems, composed in a threefold volume, are instinct with his personality and vigorous charm. "Hymns Occasional, Hymns Temporary, Hymns Personall" are the names of the three parts; they are written, as he tells us, "that all Persons, according to their Degrees and qualities, may at all times -- be remembered to praise God, and to be mindful of their duties."

Wither in later life expresses most unnecessary repentance for his early poems. Not a single line of his poetry is really corrupt or dishonorable to the writer. But

(1) Courthope- History of English Poetry-Vol.III- page 326 
when he was young he wrote of love and the beauty of nature and the beauty of woman, with a facile pen and an ardent delight in the fulness of his life and the power of his art, which seemed no doubt profane and dangerous trifling to the Puritan captain of the Civil War.

In the preface to the "Motto", addressed to "Anybody" he says: "The language is but indifferent, for I affected matter rather than words; the method is none at all: for I was loath to make a business of recreation." It is worth noticing that in the preface he alludes to the episode which, in spite of its uncouthness and exaggeration, is perhaps the most amusing part of his satires, in very uncomplimentary terms: "The foolish Canterbury Tale in my Scourge of Vanity (which I am now almost ashamed to read over) even hath been by some praised for a witty passage." Whenever wither gives himself liberty and has his fling, he is sure not long afterwards to repent.

The following lines bear evidence of his moral and religious convictions:

"But oh! my God, though grovelling I appear, Upon the ground, and have a footing here, Which hales me downward, yet in my desire To that which is above me I aspire; And all my best affections I profess To Him that is the Sun of Righteousness. Oh! keep the morning of his incarnation, The burning noontide of his bitter passion, 
The night of his descending, and the height

of his ascension,-- ever in my sight:

That imitating Him in what I may,

I never follow an inferior way."

He realized that solace and comfort may be obtained only by reflection upon divine life:

"By my late hopes that now are crossed, Consider those that firmer be, And make the freedom I have lost,

A means that may remember thee.

Had Christ not thy Redeemer been,

What horrid state hadst thou been in" !

Also in the following lines:

"But from our duty though we swerve, Thou still dost mercy show, And deign Thy creatures to preserve That men might thankful grow; Yet, though from day to day we sin, And Thy displeasure gain, No sooner we to cry begin, But.pity we obtain."

Mr. Wilmott has shown in his "Lives of Sacred Poets", that there has been very little intelligent criticism of Wither, and that he was a much truer poet and more worthy man than it has been the custom to represent him. If I may make my own estimation of Wither, permit me

(1) Griswold, R. W.- Sacred Poets of England- page 134. 
to say that he has revealed himself in a way in which few poets have done. His was an honorable spirit, a noble and beautiful soul. I think his repentance was sincere. It is natural for one to read him not only with admiration but with sympathy. He kept close to the best that he knew. What more could one ask?

\section{HENRY VAUGHAN}

The last and one of the most important poets to be considered is Henry Vaughan (1622-95), author of "Silex Scintillans". Of this writer hardly any external facts are known. He was born in the land of the ancient Silurians and liked to call himself a silurist. He began by writing secular poetry which betrays Ben Jonson's influence -- "Olor Iscanus," finished in 1647; but an illness detached him from the world and turned his thoughts to spiritual things. He became impregnated with the poetry of George Herbert and imitated him, writing "Silex Scintillans", which appeared in two parts in 1650 and 1655. (1)

From Vaughan's works much may be confidently divined as to the influences which determined the cour se of his genius. There is, however, some difficulty in following this method of interpretation owing to the order in which his poems were published. In 1646 appeared a small volume containing translations of Juvenal. There is no trace in this of the serious and religious vein of thought in which Vaughan's

(1) Legouis, Emile- History of English Literature-Vol.I- page 355. 
most striking poems are conceived. "Silex Scintillans" appeared in 1650 and was followed, in 1651, by "Olor Iscannus" which is as different as possible from the deeply religious matter and manner of "Silex Scintillans." There are references in the book to London usurers, and frequent addresses to the friends of his youth, which, far from breathing a devotional spirit, point clearly to tastes of recklessness and dissipation in the past.

Vaughan himself never published "Olor Iscanus". It appears to have been consigned to the hands of his brother, Thomas Vaughan. In his address to the reader his brother says: "I have not the author's approbation of publication." It would appear, therefore, that Henry Vaughan wished to have destroyed these ebullitions of his youthful muse; and that they were, in the end, published contrary to his desire. Yet there is really nothing objectionable in the volume. The poems contained in it are not of a strictly religious character, but I am not aware of a line that anyone need have been ashamed of.

Vaughan is quite pathetic in the prefact to "Silex Scintillans" about his eærly loose love poetry. He suppressed the worst of it and adjures the reader to leave the sufficiently harmless collection, which escaped him, unread. After attacking the love poetry of the day he says:

$$
\text { "It is a sentence of sacred authority that 'he that }
$$
is dead is freed from sin'; because he cannot in that state,

(1) Lyte, H. F.- Poems of Vaughan-page 35. 
which is without the body, sin any more; but he that writes idle books makes for himself another body, in which he always lives, and sins after death as fast and as foul as ever he did in his life; which very consideration deserves to be a sufficient antidote against this evil disease. And here, because I would prevent a just censure by my free confession, I must remember, that I myself have, for many years together, languished of this very sickness; and it is is no long time since I have recovered. But blessed be God for it! I have by his saving assistance supprest my greatest follies, and those which escaped from me are, I think, as innoxious as most of that vein use to be; besides, they are interlined with many virtuous and some pious mixtures. What I speak of them is truth; but let no man mistake it for extenuation of faults, as if I intended an apology for them, or myself, who am conscious of so much guilt in both as can never be expiated without special sorrows, and that cleansing and pretious effusion of my Almighty Redeemer. And if the world will be so charitable as to grant my request, I do here most humbly and earnestly beg that none would read them."

A change seems to have come over his spirit, which influenced it to the close of his earthly career. He was yisited by a severe and lingering illness, of what character exactly is not specified. It was, however, of a nature to bring him to the brink of the grave, and to keep him long in a state of solitude and suffering; and, while he was in 
this condition, more deep and solem religious views and feelings appear to have broken in upon his soul than any he had before harboured. The high and holy claims of God; the infinite importance of eternity; the worthlessness of the world, and the folly of living for it; the baseness of $\mathrm{sin}$, and the consequences of indulging in it, .- all seem to have pressed heavily on his mind at this crisis, and to have filled him with great humility and seriousness.

Vaughan's religion is deep, lively, personal, tender and impassioned. He is an Anglican mystic. The pervading atmosphere of mystic rapture constitutes the main charm of his poems.

His religious poems exhibit considerable originality and picturesque grace and breathe forth a high strain of morality and piety:

"To thee, who with true light art clad, And seest all things just as they be, Look from thy throne upon this roll of heavy sins, my high transgressions, Which I confesse with all my soul; My God, accept of my confession?"

He plainly admits the errors of his youth, in the poem, "The Garland":

"When first my youthful, sinful age Grew master of my ways, Appointing error for my page,

(1) Lyte, H. F.- Works of Vaughan-page 128. 
And darkness for my days;

- I flung away, and with full cry

of wild affections, rid

In post for pleasures, bent to try

All gamesters that would bid.

Gave my fond humors their full wing

And drowned my head with roses."

I think the verse which preserves Vaughan's name in fragrant memory is contained in the "Silex scintillans". In many lyrics he waxes didactic, and moralized upon man and God in a way not edifying to the present-day peaders, if it was when they were composed. But when inspiration visited him, and he could write such a unique poem as "The Retreate" -- a kind of seventeenth century forerunner of Wordsworth's "Ode"-- or an exquisite poem like "They Are 211 Gone", Vaughan found lyric for the spiritual mood such as few men have found in the whold range of British song. His religion did not clog his poetry but lent it wings; and no more sincere and intimate personal profession of faith can be named. 
SUMMARY

- Thus we have traced through these seventeenth century parets the tendency to personal retractation or literary repentance.

It is a difficult task to form one's own conclusion as to the nature, depth and meaning of such confessions in literature. Here we find the serious, conscious artist who would sacrifice everything rather than be untrue to his Muse. He looks upon worldy things as matters of little value; he seeks consolation in musings upon the divine aspects of his art. On the other hand, we see the deeply religious poet who seeks to warn the world of its follies and sins. To drive home his moral, he looks back upon the sins of his youth and makes confession.

It is a difficult thing to try to judge the sincerity and nature of these confessions. Some critics are prone to judge too severely and look upon these writers as men who sought to make personal advancement by means of repentance. I cannot take this attitude. One must read Elizabethan poetry closely and sympathetically, and try to understand that beneath the personal convictions of each poet there are certain great influences that were brought to bear upon the literature of the age. Stern Puritanism was going deeper and deeper into the heart of English life and thought; and it was this one tendency of Puritanical thought to reflect and moralize that influenced seventeenth century poets to make their personal retractation or literary repentance. 
Allibone, S. A. - Dictionary of Authors,

Alden, R. A.- The Rise of Formal Satire in England, Philadelphia, 1899.

Aldrich, T. B.- $\frac{\text { Poems of Herrick, }}{\text { New York, 1900. }}$

Bullen, A. H. - The Elizabethans,

Benham, A. R.- English Literature from Widwith to Chaucer, Yale University Press, 1916.

Boas, R. B.- Social Backgrounds of Finglish Literature, Boston, 1923 .

Brett-Smith, H. F.- The Unfortunate Traveller,

Brooke, S. A.- English Literature, London, 1880.

Chambers, w. \& R.- Cyclopaedia of English Literature, London, 1902.

Cambridge History of English Literature, New York, 1907.

Cambridge Modern History, New York, 1902:

Camden Society Publications, (1884) Letter-book of Gabriel Harvey.

Camden Society Publications, (1848) Machyn's Chronicle.

Carpenter, F. E. - A Reference Guide to Edmund Spenser, Chicago, 1923.

Church, R. W. - Edmund Spenser, New York, 1902.

Clarendon, Lord- Life of Carew,

Clark, D. H.- $\frac{\text { Rhetoric and Poetry in the Renaissance, }}{\text { New York, 1922. }}$ 
Collins, J. C. - The Plays and Poems of Greene,

Cory, H. E.- Edmund Spenser, University of California Press, 1917.

Courthope, W. J.- $\frac{\text { A History of English Poetry, Vols. I, V., }}{\text { New York, 1895-1905. }}$

Craik, Henry- English Prose,

Dark, Sidney- Five Deans (Biography of Donne)

De La Mare, Walter- Edinburgh Review, 1913.

Dickinson, T. H.- Robert Greene, New York, 1909 .

Dictionary of National Biography, New York, 1885.

Disraeli, Isaac- Calamities and Quarrels of Authors,

Dodge, R. E. N.- $\frac{\text { Complete Poetical Works of Spenser, }}{\text { Boston, 1908. }}$

Donne, John- Poetical Works,

Dowden, E. - New Studies in Literature, London, 1902 .

Dyce, A.- Works of Greene and Peele,

Einstein, I. D. - $\frac{\text { Tudor Ideals, }}{\text { New York, 1921. }}$

Erskine, John- The Elizabethan Iyric,

Fausset, H. I.- John Donne, New York, 1924 .

Fletcher, J. B.- Publications Modern Language Association, 1926.

Fletcher, J. B.- Modern Philology, VIII, 1911.

Froude, J. A.- History of England, New York, 1899. 
Garnett and Gosse- English Literature,

Gascoigne, G.- Complete Works, Cambridge, 1907.

Gosse, E. W.- Seventeenth Century Studies, New York, 1897.

Greene, Robert- Groatsworth of Wit, New York, 1923.

Greenlaw, Edwin- Outline of Literature of the English Renaissance, New York, 1916.

Greenlaw, E.- Studies in Philology, XVII, 1920.

Grierson, H. J.C.- The Poems of John Donne, oxford, 1912.

Griswold, R. W.- The Sacred Poets of Fingland and America, New York, 1848.

Grosart, A. B.- Works of Nash, Edinburgh, 1883-4.

Hannay, David- The Later Renaissance,

Harrison, J. S.- Platonism in English Poetry, London, 1915. Hart, J. S.- $\frac{\text { Essays on the Life and Writings of Spenser, }}{\text { New York, 1847. }}$

Harvey, Gabriel- Fowre Letters, London, 1922.

Haslewood, Joseph- Ancient Critica 1 Essays, London, 1811.

Hazlitt, Wm.- Lectures on the English Poets, London, 1870.

Henslowe, Philip- Henslowe Papers, London, 1907.

Higginson, J. J.- $\frac{\text { Spenser's Shepherd's Calender, }}{\text { New York, } 1912}$

Herford, C.H.- Literary Relations of Fngland and Germany in the Sixteenth century,

Cambridge, 1886. 
Herrick, R.- Hesperides; or the Works Both Human and Divine, Boston, 1856 .

Holliday, Carl- Cavalier Poets,

Hulme, E. M. - The Renaissance,

Jusserand, J. A. - The English Novel in the Time of Shakespeare, London, 1890 .

Jusserand, J. A.- - Literary History of the English People,

Kirkland, C. M.- $\frac{\text { Spenser and the Faery Queen, }}{\text { New York, 1848. }}$

Krapp, G. P.- The Rise of English Literary Prose,

Lamed, J. N.- The New Lamned History, Springfield, Mass.,1922.

Lee, Sir Sidney- Shakespeare's England, oxford, 1917.

Legouis, Pierre- Donne, the Craftsman, Paris, 1928.

Legouis, Emile- History of English Literature, London, 1926.

Legouls, Emile- Edmund Spenser,

Leigh, Oliver- English Belles-Lettres from 901 to 1834 , London, 1901.

Lynd, Robert- $\frac{\text { Books and Authors, }}{\text { New York, 1923. }}$

Lynd, Robert- $\frac{\text { The Art of Letters, }}{\text { London, } 1921 \text {. }}$

Lyte, H. F.- The Poems of Vaughan,

Martin, L. C.- The Works of Henry Vaughan,

Michigan University, Dept. of English, Studies in Shakespeare, Milton and Donne, New York, 1925. 
Mooorman, F. W.- Poetical Works of Robert Herrick, London, 1921.

Osgood, C. G.- Studies in Philology, XIV, 1917.

Padelford, F. M.- Modern Philology, XIV, 1916.

Robertson, J. M.- Elizabethan Literature,

Renwick, W. L.- Edmund Spenser,

Saintsbury, G. E. B.- The Earlier Renaissance, London, 1925.

Saintsbury, G. E. B.- History of English Literature, London, 1891.

Schelling, F. E.- A Book of Elizabethan Lyrics, Boston, 1903.

Schelling, F. E.- $\frac{\text { A Book of Seventeenth Century Lyrics, }}{\text { Boston, 1899. }}$

Schofield, W. H.- Chivalry in English Literature, New York, 1912 .

Shakespeare Society- Publications (1841-53) Vol. XII.

Simpson, E. M. - Study of Donne's Prose Works,

Sheavyn, Phoebe- The Literary Profession in the Elizabethan Age, Manchester, 1923.

Smith, L. P.- Donne's Sermons,

Spingarn, J. E.- History of Literary Criticism, in the Renaissance, London, 1925.

Stephen, Leslie- National Review, Vol. XXXIV.

Symons, Arthur- Figures of Several Centuries, New York, 1916 .

Symons, Arthur- Fortnightly Review, (New Series) Vol. LXVI.

Tatlock, J. S.- Publications Modern Language Association, Dec. 1913. 
Taylor, H. O.- Thought and Expression in the Sixteenth Century,

Væughan, H.- Silex Scintillans, etc., London, 1900.

Vaughan, H.- The Sacred Poems, etc.,

Walton, Izaak- $\frac{\text { Life of Donne, }}{\text { London, 1898. }}$

Ward, T. H.- The English Poets, New York, 1903.

Warton, Thomas - History of English Poetry,

Wendell, Barrett- The Temper of Seventeenth Century in English Literature, New York, 1904.

Wilmott, R. A.- English Sacred Poetry, of the 16, 17, 18, 19, Centuries,

Winstanley, I.- Modern Language Quarterly III. 